\title{
Pendeteksian Kecurangan Laporan Keuangan dengan Beneish M-Score pada Perusahaan Perbankan Terbuka
}

\author{
Yanuary Eka Christy \\ Universitas Ma Chung \\ ynchrr@gmail.com. \\ Daniel Sugama Stephanus \\ Universitas Ma Chung
}

\begin{abstract}
This study aims to determine the percentage of firms listed on the BEI in 2014-2016 which are classified as non manipulator, gray company and manipulator by using five indexes of Days Sales in Receivable Index (DSRI), Gross Margin Index (GMI), Asset Quality Index (AQI), Sales Growth Index (SGI), and Total Accrual To Total Assets Index (TATA). The method of collecting data is documentation with the number of samples are 42 banking companies listed on BEI Year 2014-2016. Data analysis used is Beneish Ratio Index. The results revealed that the percentage of banking companies classified as non manipulator in 2014 amounted to $4.76 \%$, by $201538.1 \%$ and in 2016 47.6\%. The percentage of banking companies classified as gray company in 2014 amounted to $38.1 \%$, by 2015 50\% and in $201645.2 \%$. Percentage of banking companies that are classified as manipulators in 2014 amounted to 57.1\%, in $201511.9 \%$ and in $20167.14 \%$.
\end{abstract}

Keywords: Beneish Model, Early Detection, Financial Report Fraud, gray company, manipulator and non manipulator.

\begin{abstract}
Abstrak
Penelitian ini bertujuan untuk mengetahui persentase perusahasan perbakan yang terdaftar di BEI tahun 2014-2016 yang tergolong sebagai non manipulator, grey company dan manipulator dengan mennggunakan lima index hitung Days Sales in Receivable Index (DSRI), Gross Margin Index (GMI), Asset Quality Index (AQI), Sales Growth Index (SGI), dan Total Accrual To Total Assets Index (TATA). Metoda pengumpulandata adalah dokumentasi dengan jumlah sampel adalah 42 perusahaan perbankan yang terdaftardi BEI Tahun 2014-2016. Analisis data yang digunakan adalah Beneish Ratio Index. Hasil penelitian mengungkapkan bahwa persentases perusahaan perbankan yang tergolong sebagai non manipulator pada tahun 2014 sebesar 4,76\%, tahun 2015 38,1\% dan tahun 2016 47,6\%. Persentase perusahaan perbankan yang tergolong sebagai grey company pada tahun 2014 sebesar 38,1\%, tahun 2015 $50 \%$ dan tahun 2016 45,2\%. Persentases perusahaan perbankan yang tergolong sebagai manipulator pada tahun 2014 sebesar 57,1\%, tahun 2015 11,9\% dan tahun 2016 7,14\%.
\end{abstract}

Kata kunci: Beneish Model, Deteksi dini, Grey Company, Kecurangan Laporan keuangan, non manipulator, manipulator 


\section{PENDAHULUAN}

Laporan keuangan merupakan instrumen yang sangat penting bagi suatu entitas yang digunakan sebagai alat komunikasi antara data keuangan dengan pihak-pihak pengguna lapran keuangan. Menurut PSAK No. 1 (2015), menyatakan bahwa tujuan laporan keuangan adalah untuk memberikan informasi mengenai posisi keuangan, kinerja keuangan dan arus kas entitas yang bermanfaat bagi sebagian besar kalangan pengguna laproan dalam pembuatan keputusan ekonomi. Menyadari pentingnya kandungan informasi dalam laporan keuangan tidak menutup kemungkinan dapat terjadi salah saji baik dikarenakan kekeliruan atau kecurangan oleh perilaku manajer perusahaan. Dampak yang timbul dari adanya kecurangan laporan keuangan adalah dapat mengurangi tingkat kepercayaan dan merugikan para pemangku kepentingan seperti kreditor, investor, karyawan, dan juga pemerintah.

Kecurangan laporan keuangan merupakan tindakan manipulasi terhadap isi laporan keuangan dengan tujuan untuk mendapatkan keuantungan secara pribadi. Kecurangan laporan keuangan merupakan salah satu bagian dari tiga jenis kecurangan yang ada. berdasarkan Report To The Nation Association of Certified Fraud Examiners (2016), terdapat tiga jenis kasus kecurangan yang menjadi perhatian global yaitu asset Misappropriation, Corruption dan Financial Statement Fraud. Dalam survai global yang dilakukan oleh ACFE (2016), menyatakan bahwa kasus Asset Misappropriation merupakan kasus kecurangan terbesar dengan persentase sebesar $83,5 \%$ dari jumlah kasus lebih dari 83\%. Korupsi menempati posisi kedua setelah Asset Misappropriationdengan persentase sebesar 35,4\%. Financial Statement Fraud mendapatkan persentase sebesar 9,6\%. Meskipun Financial Statement Fraud mendapatkan persentase yang cukup rendah, namun tingkat kerugian yang ditimbulkan cukup tinggi yaitu sebesar \$975.000 pada tahun 2016. Hal ini membuktikan bahwa Financial Statement Fraud perlu mendapatkan penanganan secara serius agar tidak menimbulkan tingkat kerugian yang lebih tinggi. Begitu banyaknya jenis-jenis tindakan kecurangan, tentu banyak hal yang dapat memicu terjadinya tindakan kecurangan tersebut. Beberapa hal yang dapat memicu terjadinya kecurangan antara lain seperti tekanan, kesempatan dan rasionalisasi yang ada

Menurut Association of Certified Fraud Examiners (2016), dalam survai frand Indonesia menyatakan bahwa jenis Fraud yang paling merugikan Indonesia adalah 77\% korupsi, 19\% penyalagunaan aktiva dan 4\% kecurangan laporan keuangan. Berdasarkan survai yang dilakukan oleh ACFE Indonesia tahun 2016 menyebutkan bahwa laporan keuangan menjadi salah satu media utama ditemukannya fraud. Sekalipun persentase kecurangan laporan keuangan yang masih tergolong rendah, namun kerugian yang diakibatkan dari kasus tersebut cukup besar. Hal ini dibuktikan dengan adanya survei yang dilakukan oleh ACFE 2016 yang menyatakan bahwa kerugian yang ditimbulkan mencapai lebih dari Rp10 Miliar (Survai ACFE, 2016). Sehingga, fraud terhadap laporan keuangan perlu mendapatkan perhatian secara secara serius agar tidak menimbulkan sebuah masalah bagi para pengguna laporan keuangan yang akan berpengaruh terhadap pengambilan keputusan.

Kasus pemberian dana talangan Bank Century. Kasus tersebut merupakan kasus terbesar yang merugikan negara dengan cara merampas uang negara lebih dari Rp. 7 Triliyun dalam bentuk bailout. Dalam kasus Bank Century tidak dilakukan oleh pejabat bank saja, namun melibatkan banyak pihak seperti aparat kepolisian, lembaga pembuat kebijakan perbankan bahkan beredar isu keterkaitan presiden dalam kasus tersebut (Aditjondro, 2010).

Berdasarkan beberapa isu kecurangan yang terjadi di dunia perbankan, pihak Otoritas Jasa Keuangan mengatakan bahwa jenis kasus tindak pidana perbankan yang terjadi pada tahun 2014 hingga triwulan III tahun 2016 adalah 55\% kasus kredit, 21\% rekayasa pencatatan, 15\% 
penggelapan dana, 5\% transfer dana dan 4\% kasus pengadaan aset. (www.finance.detik.com, 2016). Untuk mengurangi potensi kecurangan yang ada, diharapkan perbankan mampu menjalankan kegiatan operasionalnya berdasarkan prinsip kehati-hatian.

Banyaknya skandal akuntansi yang terjadi merupakan salah satu alasan penting untuk dilakukannya analisis terhadap laporan keuangan untuk meminimalisir tindak kecurangan laporan keuangan serta dapat mendeteksi sejak dini adanya aktivitas kecurangan sebelum menjadi kasus besar yang dapat merugikan negara. Salah satu alat yang digunakan untuk mengetahui adanya manipulasi adalah dengan menggunakan benesih ratio index yang dipopulerkan oleh Beneish (1999). Pada penelitian yang dilakukan oleh Beneish digunakan rasio-rasio yang terdapat pada laporan keuangan. Rasio-rasio Beneish $M$-Score yang digunakan untuk menggambarkan adanya manipulasi laporan keuangan adalah Days Sales in Receivable Index (DSRI), Gross Margin Index (GMI), Asset Quality Index (AQI), Sales Growth Index (SGI), Depreciation Index (DEPI), Sales General and Administrative Expenses Index (SGAI), Leverage Index (LVGI) dan Total Accrual To Total Assets Index (TATA)

Berdasarkan penelitian tersebut, diketahui bahwa pentingnya dalam menganalisis laporan keuangan untuk mengetahui apakah laporan keuangan tersebut terindikasi kecurangan atau tidak. Hal inilah yang mendasari penulis untuk melakukan penelitian mengenai analisis kecurangan laporan keuangan pada perusahaan perbankan yang terdaftar di Bursa fek Indonesia (BEI) Tahun 2014-2016.Alat deteksi yang digunakan dalam penelitian ini adalah Beneish M-Scoredengan menggunakan lima variabel Days Sales in Receivable Index (DSRI), Gross Margin Index (GMI), Asset Quality Index (AQI), Sales Growth Index (SGI), dan Total Accrual To Total Assets Index (TATA). Penelitian ini memberikan sumbangan pemikiran mengenai pendeteksian kecurangan laporan keuangan dengan perhitungan beneish ratio index

\section{TINJAUAN LITERATUR}

\section{Definisi Kecurangan (Fraud)}

Fraud menurut Bologna et al. (1995) dalam Lediastuti dan Subandijo (2014) adalah tindakan penipuan kriminal yang bermaksud untuk memberi manfaat keuangan kepada penipu dan merupakan salah satu tindak pidana. Fraud dapat diistilahkan sebagai kecurangan yang mengandung makna suatu penyimpangan dan perbuatan melangar hukum (illegal act), yang dilakukan dengan sengaja untuk tujuan tertentu misalnya menipu atau memberikan gambaran keliru (mislead) kepada pihak-pihak lain, yang dilakukan oleh orang-orang baik dari dalam maupun dari luar organisasi. Kecurangan dirancang untuk memanfaatkan peluang-peluang secara tidak jujur, yang secara langsung maupun tidak langsung merugikan pihak lain (Karyono, 2013).

\section{Fraud Triangle}

Menurut Cressey (1953) terdapat tiga faktor yang menjadi penyebab terjadinya fraud yaitu tekanan (pressure), peluang (opportunity), dan pembenaran (rationalization).

1. Tekanan (Pressure)

Lediastuti dan Subandijo (2014) menjelaskan bahwa untuk melakukan fraud lebih banyak tergantung pada kondisi individu seperti masalah keuangan maupun tekanan non finansial. Kondisi yang mendesak menjadikan seseorang memiliki tekanan untuk mengatasi permasalahan tersebut dengan cara melakukan tindakan fraud.

2. Peluang (Opportunity)

Menurut Zulkarnain (2013), Opportunity adalah peluang yang memungkinkan fraud terjadi biasanya dikarenakan lemahnya sistem pengendalian internal yang ada dalam organisasi, kurangnya pengawasan, dan penyalahgunaan wewenang. 


\section{Pembenaran (Rationalization)}

Pembenaran adalah pemikiran yang menyatakan bahwa tindakannya dalam melakukan tindakan fraud merupakan hal yang sah-sah saja dan dapat diterima dalam masyarakat. Hal ini terjadi karena pelaku tindak fraud merasa bahwa mereka layak mendapatkan keuntungan lebih atas apa yang telah mereka kerjakan. Selain itu, hal tersebut juga dilakukan untuk menenangkan perasaan pelaku sehingga jika dilakukan dapat mengurangi Fraud pada umumnya dipicu oleh motivasi dan kesempatan.

\section{Beneish M-Score}

Beneish M-Score dikembangkan oleh Profesor Messod Beneish. Variabel yang diukur menggunakan data dari tahun yang ditentukan $(\mathrm{t})$ dan menggunakan data tahun sebelumnya ( $\mathrm{t}$. 1). Beneish M-Score diperoleh dari hasil perhitungan yang robust. Keterbatasan Beneish MScore adalah model ini merupakan model probabilistik sehingga tidak dapat mendeteksi fraud dengan ketepatan $100 \%$. Selain itu, model ini hanya dapat mengestimasikan informasi keuangan perusahaan publik. Artinya model ini tidak bisa digunakan untuk perusahaan private atau non-publik. Keterbatasan lain adalah manipulasi pendapatan hanya dapat terdeteksi pada kelebihan saji daripada kekurangan saji. Jadi model ini tidak dapat digunakan untuk mempelajari perusahaan yang beroperasi dalam keadaan yang kondusif untuk penurunan laba (Beneish, 1999). Beneish M-Score adalah sebuah metoda untuk membantu mengungkap perusahaan yang kemungkinan melakukan fraud terhadap pendapatan yang dicatat dalam dalam laporan keuangan (Beneish, 2012).

\section{Beneish Ratio Index}

Beneish Ratio Indexadalah suatu teknik yang digunakan untuk menganalisis laporan keuangan dalam mendeteksi ada atau tidaknya kecurangan laporan keuangan. Hal tersebut dibuktikan oleh Beneish (1999) yang telah melakukan penelitian perbedaan kuantitatif antara perusahaan yang terindentifikasi melakukan manipulasi laba dan yang tidak melakukan manipulasi laba. Beneish melakukan analisis dengan menggunakan data keuangan lalu menghitung rasio keuangan. Hal tersebut dilakukan untuk mengetahui apakah terdapat indikasi manipulasi terhadap laporan keuangan atau tidak. Beneish (1999) mengungkapkan bahwa pada umumnya manipulasi laba ditunjukkan dengan peningkatan atas pendapatan/penurunan atas beban perusahaan secara signifikan dari satu tahun $(\mathrm{t})$ ke tahun sebelumnya (t-1)

Beneish M-Score diukur dengan menggunakan lima rasio dan telah dimodifikasi oleh beberapa peneliti (Mavengere 2015; Paolone dan Magazzino 2014). Hanya lima rasio model score yang menghasilkan hasil yang signifikan. Dalam penelitian sebelumnya, Roxas (2011) menegaskan bahwa model score, dengan lima rasio, dapat mengidentifikasi manipulasi laba lebih akurat daripada delapan rasio (Abbas, 2017)

\section{METODA PENELITIAN}

\section{Jenis Penelitian}

Jenis penelitian yang digunakan dalam penelitan ini adalah penelitian kuantitatif dengan pendekatan deskriptif. Menurut Arikunto (2014), penelitian kuantitatif merupakan penelitian yang dalam prosesnya menggunakan angka-angka, mulai dari proses pengumpulan data, penafsiran data, serta penampilan hasilnya.

\section{Populasi dan Sampel}

Populasi merupakan keseluruhan dari subyek penelitian (Arikunto, 2014). Dalam penelitian ini populasi yang digunakan adalah perusahaan perbankan yang terdaftar di Bursa Efek Indonesia pada tahun 2014-2016 yang berjumlah 42 perusahaan. Sampel merupakan 
sebagian atau wakil populasi yang diteliti (Arikunto, 2014). Dalam penelitian ini sampel yang diambil menggunakan metoda purposive sampling yaitu pengambilan sampel yang didasari oleh beberapa kriteria. Adapun kriteria yang digunakan adalah sebagai berikut.

1. Perusahaan perbankan yang terdaftar di Bursa Efek Indonesia yang menerbitkan laporan keuangan perioda 31 Desember 2014-2016

2. Menerbitkan laporan keuangan dengan denominasi rupiah.

3. Laporan keuangan memiliki data-data yang berkaitan dengan variabel yang dibutuhkan dalam penelitian.

\section{Jenis dan Sumber Data}

Jenis data yang digunakan pada penelitian ini adalah jenis data kuantitatif. Data kuantitatif yang digunakan dalam penelitian ini diperoleh dari sumber data sekunder. Menurut Sekaran dan Bougie (2017), penelitian kuantitatif merupakan penelitian yang bertitik tolak dari peristiwa-peristiwa yang dapat diukur secara kuantitatif atau dinyatakan dengan angka-angka. Sedangkan menurut Arikunto (2014), penelitian kuantitatif merupakan penelitian yang dalam prosesnya menggunakan angka-angka, mulai dari proses pengumpulan data, penafsiran data, serta penampilan hasilnya.

Menurut Sekaran dan Bougie (2017), data sekunder merupakan data yang mengacu pada informasi yang dikumpulkan dari sumber yang ada yaitu catatan atau dokumentasi perusahaan, publikasi pemerintah, analisis industri oleh media, situs web, internet dan sebagainya. Sumber data yang digunakan dalam penelitian ini adalah data sekunder yaitu berupa Laporan keuangan perusahaan perbankan tahun 2014-2016yang berasal dari website Bursa Efek Indonesia (www.bei.com).

\section{Definisi Operasional dan Pengukuran Variabel}

Variabel yang digunakan pada penelitian ini adalah Beneish M-Score. Beneish M-Score membantu mengungkap perusahaan yang kemungkinan melakukan fraud terhadap pendapatan yang dicatat dalam dalam laporan keuangan. Beneish M-Score terdiri beberapa variabel yaitu sebagai berikut.

1. DSRI: Indeks jumlah hari dalam penerimaan hasil piutang atas penjualan (Day's Sales in Receivable Index). Menurut Kartika dan Irianto (2010), rasio ini membandingkan piutang usaha terhadap penjualan yang dihasilkan perusahaan pada suatu tahun $(\mathrm{t})$ dan tahun sebelumnya ( $\left.\mathrm{t}_{-1}\right)$. Kenaikan yang besar pada DSRI merupakan hasil dari perubahan dalam keijakan kredit untuk meningkatkan penjualan dalam menghadapi persaingan yang ada. Tetapi, ketidakseimbangan pada peningkatan piutang secara relatif terhadap penjualan dapat mengindikasikan adanya lonjakan pendapatan. Sehingga, kenaikan yang cenderung besar pada DSRI memiliki keterkaitan adanya kemungkinan pencatatan penjualan dan pendapatan yang terlalu besar.

$D S R I=\frac{\text { Piutang Usaha }_{(t)} / \text { Penjualan }_{(t)}}{\text { Piutang Usaha }_{(t-1)} / \text { Penjualan }_{(t-1)}}$ 
2. GMI: Indeks atas Laba Kotor (Gross Margin Index). Menurut Kartika dan Irianto (2010), Indeks atas laba kotor merupakan rasio yang mengukur tingkat profitabilitas perusahaan, rasio ini merepresentasikan prospek perusahaan di masa depan. Beneish (1999) menyatakan jika gross margin memburuk akan berdampak negatif pada prospek perusahaan. Jadi, jika perusahaan memiliki prospek yang buruk maka akan lebih banyak terdapat manipulasi.

$$
\text { GMI }=\frac{\text { Laba Kotor }_{(\mathrm{t}-1)} / \text { Penjualan }_{(\mathrm{t}-1)}}{\text { Laba Kotor }_{(\mathrm{t})} / \text { Penjualan }_{(\mathrm{t})}}
$$

3. AQI: Indeks atas Kualitas Aset (Asset Quality Index). Menurut Kartika dan Irianto (2010), AQI menunjukkan kualitas aktiva tidak lancar perusahaan yang kemungkinan akan memberikan manfaat bagi perusahaan di masa depan. Beneish (1999) menyatakan bahwa semakin tinggi rasio, maka diyakini perusahaan melakukan peningkatan biaya tangguhan/meningkatkan aset tidak berwujud dan manipulasi pendapatan.

$$
\mathrm{AQI}=\frac{1-\frac{\text { Aktiva lancar }_{(\mathrm{t})}+\text { Aktiva }_{\text {Tetap }}(\mathrm{t})}{\operatorname{Total~Aktiva}_{(\mathrm{t})}}}{1-\frac{\text { Aktiva Lancar } \left._{(\mathrm{t}-1)}\right)^{+ \text {Aktiva }_{\text {tetap }}(t-1)}}{\operatorname{Total~Aktiva~}_{(\mathrm{t}-1)}}}
$$

4. SGI: Indeks atas Pertumbuhan Penjualan (Sales Growth Index). Menurut Kartika dan Irianto (2010), Jika SGI >1, maka hal ini menunjukkan terjadinya peningkatan atas penjualan, sedangkan penurunan atas rasio ini menunjukkan adanya penurunan atas penjualan.

$$
\text { SGI }=\frac{\text { Penjualan }(t)}{\text { Piutang Usaha }(t-1)}
$$

5. TATA: Indeks atas Total Akrual terhadap Total Aktiva (Total Accruals to Total Assets). Menurut Kartika dan Irianto (2010), total akrual yang tinggi menunjukkan tingginya jumlah laba akrual yang dimiliki oleh perusahaan. Jika akrual bernilai positif ada kemungkinan manipulasi pendapatan yang lebih tinggi.

$$
\text { TATA }=\frac{\text { Laba Usaha }_{(t)-\text { Arus Kas dari Aktivitas Operasi }_{(t)}}}{\text { Total Aktiva }_{(t)}}
$$

\section{Teknik Analisis Data}

Dalam penelitian ini, peneliti menggunakan Beneish M-Score dengan teknik indeks analisis rasio yang digunakan untuk memprediksi adanya indikasi kecurangan terhadap laporan keuangan perusahaan, sehingga dapat menjadi acuan untuk menentukan perusahaan yang tergolong manipulator, non manipulator atau grey company. Dengan menggunakan lima indeks indikator Beneish perusahaan-perusahaan diklasifikasikan sebagai perusahaan non manipulator, grey company dan manipulator. Perusahaan dengan Beneish M-Score lebih tinggi memiliki kemungkinan lebih untuk melakukan fraud. Beneish M-Score merupakan model probabilistik, sehingga tidak akan mendeteksi fraud dengan ketepatan 100\%.

a) Menghitung Beneish M-Score perusahaan sesuai dengan rumus masing -masing variabel

b) Membandingkan Index Hitung dengan menggunakan Index parameter. 
1. Days Sales In Receivable Index (DSRI)

Tabel 2

Indeks Parameter Days Sales in Receivable Index (DSRI)

\begin{tabular}{|c|l|l|}
\hline No & \multicolumn{1}{|c|}{ Index } & \multicolumn{1}{|c|}{ Keterangan } \\
\hline 1 & $\leq 1,031$ & Non Manipulator \\
\hline 2 & $\leq 1,031<$ index $<1,465$ & Grey Company \\
\hline 3 & $\geq 1,465$ & Manipulator \\
\hline
\end{tabular}

2. Gross Margin Index (GMI)

Tabel 3

Index Parameter Gross Margin Index (GMI)

\begin{tabular}{|c|l|l|}
\hline No & \multicolumn{1}{|c|}{ Index } & \multicolumn{1}{|c|}{ Keterangan } \\
\hline 1 & $\leq 1,041$ & Non Manipulator \\
\hline 2 & $\leq 1,041<$ index $<1,193$ & Grey Company \\
\hline 3 & $\geq 1,193$ & Manipulator \\
\hline
\end{tabular}

3. Asset Quality Index (AQI)

Tabel 4

Indeks Parameter Asset Quality Index (AQI)

\begin{tabular}{|c|l|l|}
\hline No & \multicolumn{1}{|c|}{ Index } & \multicolumn{1}{|c|}{ Keterangan } \\
\hline 1 & $\leq 1,039$ & Non Manipulator \\
\hline 2 & $\leq 1,039<$ index $<1,254$ & Grey Company \\
\hline 3 & $\geq 1,193$ & Manipulator \\
\hline
\end{tabular}

4. Sales Growth Index (SGI)

Tabel 5

Indeks Parameter Sales Growth Index (SGI)

\begin{tabular}{|c|l|l|}
\hline No & \multicolumn{1}{|c|}{ Index } & \multicolumn{1}{|c|}{ Keterangan } \\
\hline 1 & $\leq 1,134$ & Non Manipulator \\
\hline 2 & $\leq 1,134<$ index $<1,607$ & Grey Company \\
\hline 3 & $\geq 1,607$ & Manipulator \\
\hline
\end{tabular}

5. Total Accruals to Total Assets (TATA)

Tabel 3

Indeks Parameter Total Accruals to Total Assets (TATA)

\begin{tabular}{|c|l|l|}
\hline No & \multicolumn{1}{|c|}{ Index } & \multicolumn{1}{|c|}{ Keterangan } \\
\hline 1 & $\leq 0,018$ & Non Manipulator \\
\hline 2 & $\leq 0,018<$ index $<0,031$ & Grey \\
\hline 3 & $\geq 0,031$ & Manipulator \\
\hline
\end{tabular}




\section{Indeks parameter Rasio}

Tabel 7

Indeks Parameter Rasio

\begin{tabular}{|c|l|c|l|}
\hline No & \multicolumn{1}{|c|}{ Rasio } & $\begin{array}{c}\text { Indeks } \\
\text { Parameter }\end{array}$ & \multicolumn{1}{c|}{ Keterangan } \\
\hline 1 & DSRI & $>1$ & Peningkatan Piutang \\
\hline 2 & GMI & $>1$ & Penurunan Laba Kotor \\
\hline 3 & AQI & $>1$ & Penurunan Kualitas Aktiva \\
\hline 4 & SGI & $>1$ & Peningkatan Penjualan \\
\hline 5 & DEPI & $>1$ & Penurunan Depresiasi \\
\hline 6 & SGAI & $<1$ & Peningkatan Beban Operasional \\
\hline 7 & LVGI & Bernilai positif & $\begin{array}{l}\text { Peningkatan Transaksi Akrual dalam } \\
\text { pengakuan Pendapatan }\end{array}$ \\
\hline 8 & TATA & \multicolumn{2}{|c|}{} \\
\hline
\end{tabular}

Angka indeks perusahaan yang berada pada angka indeks manipulator dan angka indeks nonmanipulator serta perusahaan yang tergolong sebagai Grey company.

c) Menentukan perusahaan yang tergolong manipulator atau nonmanipulator dengan kriteria sebagai berikut. (Darmawan, 2016)

1. Perusahaan yang memiliki $\geq 3$ indeks hitung yang sesuai dengan indeks parameter yang menyatakan manipulator, tergolong ke dalam manipulator.

2. Perusahaan yang memiliki $\geq 3$ indeks hitung yang sesuai dengan indeks parameter yang menyatakan nonmanipulator, tergolong ke dalam manipulator.

3. Perusahaan yang memiliki $\geq 3$ indeks hitung yang sesuai dengan indeks parameter yang menyatakan grey company, dan indeks hitung yang tidak memenuhi 2 kriteria penggolongan manipulator dan nonmanipulator dapat digolongkan sebagai grey company

d) Menghitung jumlah persentase dari perusahaan yang tergolong manipulator, non manipulator atau grey company (Fabelli, 2011)

e) Membuat grafik pertumbuhan kecurangan laporan keuangan selama 3 tahun.

\section{HASIL DAN PEMBAHASAN}

Penelitian ini menggunakan populasi seluruh perusahaan perbankan yang terdaftar di Bursa Efek Indonesia (BEI) pada perioda tahun 2014-2016. Penelitian ini menggunakan metoda purposive sampling. Setelah melakukan syarat-syarat purposive sampling diperoleh sampel yang sesuai dengan kriteria yaitu sebanyak 42 perusahaan perbankan. 
Tabel 8

Hasil Perhitungan Day's Sales in Receivable Index dan Kategori Perusahaan

\begin{tabular}{|c|c|c|c|c|c|c|c|c|}
\hline \multirow{2}{*}{ NO } & \multirow{2}{*}{$\begin{array}{c}\text { KODE } \\
\text { EMITEN }\end{array}$} & \multicolumn{3}{|c|}{ DSRI } & \multicolumn{3}{|c|}{ KATEGORI } & \multirow{2}{*}{$\begin{array}{c}\text { HASIL } \\
\text { Rata-Rata }\end{array}$} \\
\hline & & 2014 & 2015 & 2016 & 2014 & 2015 & 2016 & \\
\hline 1 & AGRO & 0,897 & 0,979 & 1,095 & $\mathrm{~N}$ & $\mathrm{~N}$ & $\mathrm{G}$ & 1,0 \\
\hline 2 & AGRS & 0,694 & 0,885 & 1,140 & $\mathrm{~N}$ & $\mathrm{~N}$ & $\mathrm{G}$ & 0,9 \\
\hline 3 & ARTO & 0,836 & 0,776 & 1,214 & $\mathrm{~N}$ & $\mathrm{~N}$ & $\mathrm{G}$ & 0,9 \\
\hline 4 & $\mathrm{BABP}$ & 1,004 & 0,920 & 1,010 & $\mathrm{~N}$ & $\mathrm{~N}$ & $\mathrm{~N}$ & 1,0 \\
\hline 5 & BACA & 0,892 & 0,900 & 0,990 & $\mathrm{~N}$ & $\mathrm{~N}$ & $\mathrm{~N}$ & 0,9 \\
\hline 6 & BBCA & 0,871 & 1,035 & 0,996 & $\mathrm{~N}$ & G & $\mathrm{N}$ & 1,0 \\
\hline 7 & BBHI & 0,922 & 0,899 & 1,051 & $\mathrm{~N}$ & $\mathrm{~N}$ & $\mathrm{G}$ & 1,0 \\
\hline 8 & BBKP & 0,956 & 1,020 & 0,966 & $\mathrm{~N}$ & $\mathrm{~N}$ & $\mathrm{~N}$ & 1,0 \\
\hline 9 & BBMD & 0,946 & 0,968 & 0,843 & $\mathrm{~N}$ & $\mathrm{~N}$ & $\mathrm{~N}$ & 0,9 \\
\hline 10 & BBNI & 0,870 & 1,061 & 1,011 & $\mathrm{~N}$ & $\mathrm{G}$ & $\mathrm{N}$ & 1,0 \\
\hline 11 & BBNP & 0,796 & 1,032 & 0,908 & $\mathrm{~N}$ & $\mathrm{G}$ & $\mathrm{N}$ & 0,9 \\
\hline 12 & BBRI & 0,116 & 1,003 & 1,024 & $\mathrm{~N}$ & $\mathrm{~N}$ & $\mathrm{~N}$ & 0,7 \\
\hline 13 & BBTN & 0,969 & 1,025 & 1,035 & $\mathrm{~N}$ & $\mathrm{~N}$ & $\mathrm{G}$ & 1,0 \\
\hline 14 & BBYB & 1,178 & 0,971 & 0,983 & $\mathrm{G}$ & $\mathrm{N}$ & $\mathrm{N}$ & 1,0 \\
\hline 15 & BCIC & 0,720 & 1,414 & 0,930 & $\mathrm{~N}$ & $\mathrm{G}$ & $\mathrm{N}$ & 1,0 \\
\hline 16 & BDMN & 0,897 & 0,947 & 1,024 & $\mathrm{~N}$ & $\mathrm{~N}$ & $\mathrm{~N}$ & 1,0 \\
\hline 17 & BEKS & 0,945 & 1,059 & 1,629 & $\mathrm{~N}$ & $\mathrm{G}$ & $\mathrm{M}$ & 1,2 \\
\hline 18 & BGTB & 0,925 & 0,926 & 1,398 & $\mathrm{~N}$ & $\mathrm{~N}$ & $\mathrm{G}$ & 1,1 \\
\hline 19 & BINA & 0,934 & 0,944 & 0,869 & $\mathrm{~N}$ & $\mathrm{~N}$ & $\mathrm{~N}$ & 0,9 \\
\hline 20 & BJBR & 1,003 & 0,992 & 1,102 & $\mathrm{~N}$ & $\mathrm{~N}$ & $\mathrm{G}$ & 1,0 \\
\hline 21 & BJTM & 0,772 & 0,932 & 0,992 & $\mathrm{~N}$ & $\mathrm{~N}$ & $\mathrm{~N}$ & 0,9 \\
\hline 22 & BMRI & 0,900 & 0,980 & 1,024 & $\mathrm{~N}$ & $\mathrm{~N}$ & $\mathrm{~N}$ & 1,0 \\
\hline 23 & BNBA & 0,935 & 0,978 & 0,957 & $\mathrm{~N}$ & $\mathrm{~N}$ & $\mathrm{~N}$ & 1,0 \\
\hline 24 & BNGA & 1,004 & 0,930 & 1,058 & $\mathrm{~N}$ & $\mathrm{~N}$ & $\mathrm{G}$ & 1,0 \\
\hline 25 & BNII & 0,904 & 1,092 & 0,982 & $\mathrm{~N}$ & $\mathrm{G}$ & $\mathrm{N}$ & 1,0 \\
\hline 26 & BNLI & 1,024 & 0,962 & 0,897 & $\mathrm{~N}$ & $\mathrm{~N}$ & $\mathrm{~N}$ & 1,0 \\
\hline 27 & BSIM & 1,011 & 0,918 & 0,911 & $\mathrm{~N}$ & $\mathrm{~N}$ & $\mathrm{~N}$ & 0,9 \\
\hline 28 & BSKW & 0,764 & 0,824 & 0,841 & $\mathrm{~N}$ & $\mathrm{~N}$ & $\mathrm{~N}$ & 0,8 \\
\hline 29 & BSDW & 0,768 & 0,866 & 0,875 & $\mathrm{~N}$ & $\mathrm{~N}$ & $\mathrm{~N}$ & 0,8 \\
\hline 30 & BTPN & 1,003 & 1,065 & 1,023 & $\mathrm{~N}$ & $\mathrm{G}$ & $\mathrm{N}$ & 1,0 \\
\hline 31 & BVIC & 0,825 & 1,079 & 1,056 & $\mathrm{~N}$ & $\mathrm{G}$ & $\mathrm{G}$ & 1,0 \\
\hline 32 & DNAR & 0,836 & 0,892 & 1,113 & $\mathrm{~N}$ & $\mathrm{~N}$ & $\mathrm{G}$ & 0,9 \\
\hline 33 & INPC & 0,964 & 0,929 & 1,104 & $\mathrm{~N}$ & $\mathrm{~N}$ & $\mathrm{G}$ & 1,0 \\
\hline 34 & MAYA & 0,898 & 0,981 & 1,153 & $\mathrm{~N}$ & $\mathrm{~N}$ & $\mathrm{G}$ & 1,0 \\
\hline 35 & MCOR & 0,910 & 0,944 & 1,058 & $\mathrm{~N}$ & $\mathrm{~N}$ & $\mathrm{G}$ & 1,0 \\
\hline 36 & MEGA & 0,920 & 0,900 & 0,907 & $\mathrm{~N}$ & $\mathrm{~N}$ & $\mathrm{~N}$ & 0,9 \\
\hline 37 & NAGA & 0,893 & 0,858 & 0,922 & $\mathrm{~N}$ & $\mathrm{~N}$ & $\mathrm{~N}$ & 0,9 \\
\hline 38 & NOBU & 0,785 & 1,114 & 1,016 & $\mathrm{~N}$ & $\mathrm{G}$ & $\mathrm{N}$ & 1,0 \\
\hline 39 & NISP & 0,830 & 1,096 & 0,983 & $\mathrm{~N}$ & $\mathrm{G}$ & $\mathrm{N}$ & 1,0 \\
\hline 40 & PNBN & 0,936 & 0,940 & 1,026 & $\mathrm{~N}$ & $\mathrm{~N}$ & $\mathrm{~N}$ & 1,0 \\
\hline 41 & PNBS & 1,376 & 0,632 & 1,279 & $\mathrm{G}$ & $\mathrm{N}$ & $\mathrm{G}$ & 1,1 \\
\hline 42 & SDRA & 2,084 & 0,198 & 1,031 & $\mathrm{M}$ & $\mathrm{N}$ & $\mathrm{G}$ & 1,1 \\
\hline
\end{tabular}

Keterangan:

$\mathrm{N}$ : Perusahaan yang tergolong sebagai Non manipulator

G: Perusahaan yang tergolong sebagai Grey Company

M: Perusahaan yang tergolong sebagai Manipulator 
Tabel 8 menampilkan angka DSRI perusahaan tahun 2014-2016 serta pengelompokkan perusahaan sebagai non manipulator, grey company dan manipulator. Pada tahun 2014 jumlah perusahaan yang tergolong sebagai non manipulator sebanyak 39 perusahaan. Jumlah perusahaan yang tergolong sebagai grey company sebanyak 2 perusahaan. Sedangkan perusahaan yang tergolong sebagai manipulator sebanyak 1 perusahaan. Pada tabel 8 perhitungan DSRI 2015 terdapat 32 perusahaan yang tergolong sebagai non manipulator. Jumlah perusahaan yang tergolong sebagai grey company sebanyak 10 perusahaan dari 42 perusahaan.

Berdasarkan tabel 8 perhitungan DSRI pada tahun 2016,jumlah perusahaan yang tergolong sebagai non manipulator sebanyak 15 perusahaan Jumlah perusahaan yang tergolong sebagai grey company sebanyak 26 perusahaan. Sedangkan hanya 1 perusahaan yang tergolong sebagai manipulator.

Tabel 9.

Hasil Perhitungan Gross Margin Index dan Kategori Perusahaan

\begin{tabular}{|c|l|c|c|c|c|c|c|c|}
\hline \multirow{2}{*}{ NO KODE } & \multirow{2}{*}{ EMITEN } & \multicolumn{3}{|c|}{ GMI } & \multicolumn{3}{c|}{ KATEGORI } & HASIL \\
\cline { 3 - 8 } & & $\mathbf{2 0 1 4}$ & $\mathbf{2 0 1 5}$ & $\mathbf{2 0 1 6}$ & $\mathbf{2 0 1 4}$ & $\mathbf{2 0 1 5}$ & $\mathbf{2 0 1 6}$ & Rata-rata \\
\hline 1 & AGRO & 1,236 & 0,958 & 1,035 & $\mathrm{M}$ & $\mathrm{N}$ & $\mathrm{N}$ & 1,1 \\
\hline 2 & AGRS & 1,582 & 0,826 & 0,856 & $\mathrm{M}$ & $\mathrm{N}$ & $\mathrm{N}$ & 1,1 \\
\hline 3 & ARTO & 1,425 & 0,937 & 0,843 & $\mathrm{M}$ & $\mathrm{N}$ & $\mathrm{N}$ & 1,1 \\
\hline 4 & BABP & 1,374 & 1,028 & 0,873 & $\mathrm{M}$ & $\mathrm{N}$ & $\mathrm{N}$ & 1,1 \\
\hline 5 & BACA & 1,338 & 1,093 & 0,887 & $\mathrm{M}$ & $\mathrm{G}$ & $\mathrm{N}$ & 1,1 \\
\hline 6 & BBCA & 1,054 & 0,960 & 0,959 & $\mathrm{G}$ & $\mathrm{N}$ & $\mathrm{N}$ & 1,0 \\
\hline 7 & BBHI & 1,215 & 0,957 & 0,877 & $\mathrm{M}$ & $\mathrm{N}$ & $\mathrm{N}$ & 1,0 \\
\hline 8 & BBKP & 1,178 & 0,999 & 0,914 & $\mathrm{G}$ & $\mathrm{N}$ & $\mathrm{N}$ & 1,0 \\
\hline 9 & BBMD & 1,093 & 1,014 & 0,994 & $\mathrm{G}$ & $\mathrm{N}$ & $\mathrm{N}$ & 1,0 \\
\hline 10 & BBNI & 1,068 & 0,973 & 1,011 & $\mathrm{G}$ & $\mathrm{N}$ & $\mathrm{N}$ & 1,0 \\
\hline 11 & BBNP & 1,174 & 0,911 & 0,829 & $\mathrm{G}$ & $\mathrm{N}$ & $\mathrm{N}$ & 1,0 \\
\hline 12 & BBRI & 1,083 & 1,004 & 0,957 & $\mathrm{G}$ & $\mathrm{N}$ & $\mathrm{N}$ & 1,0 \\
\hline 13 & BBTN & 1,229 & 0,938 & 0,955 & $\mathrm{M}$ & $\mathrm{N}$ & $\mathrm{N}$ & 1,0 \\
\hline 14 & BBYB & 1,123 & 0,985 & 0,876 & $\mathrm{G}$ & $\mathrm{N}$ & $\mathrm{N}$ & 1,0 \\
\hline 15 & BCIC & 4,043 & 0,395 & 0,484 & $\mathrm{M}$ & $\mathrm{N}$ & $\mathrm{N}$ & 1,6 \\
\hline 16 & BDMN & 1,129 & 0,977 & 0,912 & $\mathrm{G}$ & $\mathrm{N}$ & $\mathrm{N}$ & 1,0 \\
\hline 17 & BEKS & 1,254 & 1,283 & 2,171 & $\mathrm{M}$ & $\mathrm{M}$ & $\mathrm{M}$ & 1,6 \\
\hline 18 & BGTB & 1,230 & 0,935 & 0,822 & $\mathrm{M}$ & $\mathrm{N}$ & $\mathrm{N}$ & 1,0 \\
\hline 19 & BINA & 1,005 & 1,162 & 0,791 & $\mathrm{~N}$ & $\mathrm{G}$ & $\mathrm{N}$ & 1,0 \\
\hline 20 & BJBR & 1,159 & 1,023 & 0,867 & $\mathrm{G}$ & $\mathrm{N}$ & $\mathrm{N}$ & 1,0 \\
\hline 21 & BJTM & 1,317 & 1,062 & 0,942 & $\mathrm{M}$ & $\mathrm{G}$ & $\mathrm{N}$ & 1,1 \\
\hline 22 & BMRI & 1,078 & 0,986 & 0,938 & $\mathrm{G}$ & $\mathrm{N}$ & $\mathrm{N}$ & 1,0 \\
\hline 23 & BNBA & 1,256 & 1,042 & 0,881 & $\mathrm{M}$ & $\mathrm{G}$ & $\mathrm{N}$ & 1,1 \\
\hline 24 & BNGA & 1,103 & 1,007 & 0,900 & $\mathrm{G}$ & $\mathrm{N}$ & $\mathrm{N}$ & 1,0 \\
\hline 25 & BNII & 1,141 & 0,960 & 0,946 & $\mathrm{G}$ & $\mathrm{N}$ & $\mathrm{N}$ & 0,7 \\
\hline 26 & BNLI & 1,236 & 0,907 & 0,940 & $\mathrm{M}$ & $\mathrm{N}$ & $\mathrm{N}$ & 1,0 \\
\hline 27 & BSIM & 1,080 & 0,974 & 0,933 & $\mathrm{G}$ & $\mathrm{N}$ & $\mathrm{N}$ & 1,0 \\
\hline 28 & BSKW & 1,370 & 0,986 & 1,340 & $\mathrm{M}$ & $\mathrm{N}$ & $\mathrm{M}$ & 1,2 \\
\hline 29 & BSDW & 1,292 & 1,156 & 0,872 & $\mathrm{M}$ & $\mathrm{G}$ & $\mathrm{N}$ & 1,1 \\
\hline 30 & BTPN & 1,125 & 0,968 & 0,915 & $\mathrm{G}$ & $\mathrm{N}$ & $\mathrm{N}$ & 1,0 \\
\hline 31 & BVIC & 1,652 & 0,939 & 1,260 & $\mathrm{M}$ & $\mathrm{N}$ & $\mathrm{M}$ & 1,3 \\
\hline & & & & & & & \\
\hline
\end{tabular}




\begin{tabular}{|l|l|l|l|l|l|l|l|l|}
\hline 32 & DNAR & 1,649 & 0,869 & 0,943 & M & N & N & 1,2 \\
\hline 33 & INPC & 1,212 & 1,022 & 0,937 & M & N & N & 1,1 \\
\hline 34 & MAYA & 1,419 & 0,883 & 0,844 & M & N & N & 1,1 \\
\hline 35 & MCOR & 1,348 & 0,877 & 0,839 & M & N & N & 1,0 \\
\hline 36 & MEGA & 1,207 & 0,898 & 0,902 & M & N & N & 1,0 \\
\hline 37 & NAGA & 1,421 & 0,933 & 0,820 & M & N & N & 1,1 \\
\hline 38 & NOBU & 1,158 & 0,991 & 0,807 & G & N & N & 1,0 \\
\hline 39 & NISP & 1,078 & 0,988 & 0,907 & G & N & N & 1,0 \\
\hline 40 & PNBN & 1,143 & 0,964 & 0,880 & G & N & N & 1,0 \\
\hline 41 & PNBS & 0,149 & 3,941 & 2,620 & N & M & M & 1,3 \\
\hline 42 & SDRA & 1,024 & 1,721 & 0,974 & N & M & N & 1,2 \\
\hline
\end{tabular}

Pada tabel 9 dapat diketahui angka GMI perusahaan tahun 2014-2016 serta pengelompokkan perusahaan yang tergolong sebagai non manipulator, grey company dan manipulator. Pada tahun 2014 jumlah perusahaan yang tergolong sebagai non manipulator sebanyak 3 perusahaan. Jumlah perusahaan yang tergolong sebagai grey company sebanyak 17 perusahaan. Sedangkan perusahaan yang tergolong sebagai manipulator sebanyak 22 perusahaan

Berdasarkan tabel 9 perhitungan GMI 2015, jumlah perusahaan yang tergolong sebagai non manipulator sebanyak 34 perusahaan. Jumlah perusahaan yang tergolong sebagai grey company sebanyak 5 perusahaan. Sedangkan untuk perusahaan yang tergolong sebagai manipulator terdapat sebanyak 3 perusahaan

Berdasarkan tabel 9 perhitungan GMI 2016, jumlah perusahaan yang tergolong sebagai non manipulator, grey company dan manipulator adalah sebanyak 38 perusahaan yang tergolong sebagai non manipulator. Dan 4 perusahaan yang tergolong sebagai manipulator. Perusahaan yang memiliki angka GMI > 1 terdapat 18 perusahaan perbankan. Hal ini menunjukkan bahwa terjadi penurunan atas laba kotor perusahaan, yang menandakan bahwa prospek perusahaan mengalami penurunan. Jika prospek perusahaan mengalamai penurunan, maka tidak menutup kemungkinan dapat mengindikasikan adanya manipulasi lapora keuangan pada perusahaan.

Tabel 10

Hasil Perhitungan Asset Quality Index dan Kategori Perusahaan

\begin{tabular}{|c|c|c|c|c|c|c|c|c|}
\hline \multirow{2}{*}{ NO } & \multirow{2}{*}{ KODE EMITEN } & \multicolumn{3}{|c|}{ AQI } & \multicolumn{3}{|c|}{ KATEGORI } & \multirow{2}{*}{$\begin{array}{l}\text { HASIL } \\
\text { Rata-rata }\end{array}$} \\
\hline & & 2014 & 2015 & 2016 & 2014 & 2015 & 2016 & \\
\hline 1 & AGRO & 1,244 & 1,274 & 1,379 & $\mathrm{G}$ & $\mathrm{M}$ & $\mathrm{M}$ & 0,9 \\
\hline 2 & AGRS & 1,644 & 1,017 & 0,963 & $\mathrm{M}$ & $\mathrm{N}$ & $\mathrm{N}$ & 1,2 \\
\hline 3 & ARTO & 1,288 & 0,369 & 0,974 & $\mathrm{M}$ & $\mathrm{N}$ & $\mathrm{N}$ & 0,9 \\
\hline 4 & BABP & 1,156 & 1,284 & 1,076 & $\mathrm{G}$ & $\mathrm{M}$ & $\mathrm{G}$ & 1,2 \\
\hline 5 & BACA & 1,301 & 1,315 & 1,164 & $\mathrm{M}$ & $\mathrm{M}$ & $\mathrm{G}$ & 1,3 \\
\hline 6 & BBCA & 1,113 & 1,074 & 1,128 & $\mathrm{G}$ & $\mathrm{G}$ & $\mathrm{G}$ & 1,1 \\
\hline 7 & $\mathrm{BBHI}$ & 1,227 & 1,028 & 0,991 & $\mathrm{G}$ & $\mathrm{N}$ & $\mathrm{N}$ & 1,1 \\
\hline 8 & BBKP & 1,138 & 1,193 & 1,103 & $\mathrm{G}$ & $\mathrm{G}$ & $\mathrm{G}$ & 1,1 \\
\hline 9 & BBMD & 1,097 & 1,083 & 1,097 & $\mathrm{G}$ & $\mathrm{G}$ & $\mathrm{G}$ & 1,1 \\
\hline 10 & BBNI & 1,077 & 1,189 & 1,191 & $\mathrm{G}$ & $\mathrm{G}$ & $\mathrm{G}$ & 1,2 \\
\hline 11 & BBNP & 0,949 & 0,910 & 0,894 & $\mathrm{~N}$ & $\mathrm{~N}$ & $\mathrm{~N}$ & 0,9 \\
\hline 12 & BBRI & 1,279 & 1,093 & 1,125 & $\mathrm{M}$ & $\mathrm{G}$ & $\mathrm{G}$ & 1,2 \\
\hline 13 & BBTN & 1,104 & 1,190 & 1,231 & $\mathrm{G}$ & $\mathrm{G}$ & $\mathrm{G}$ & 1,2 \\
\hline
\end{tabular}




\begin{tabular}{|l|l|l|l|l|l|l|l|l|}
\hline 14 & BBYB & 1,174 & 1,258 & 1,209 & G & M & G & 1,2 \\
\hline 15 & BCIC & 0,869 & 1,043 & 1,217 & N & G & G & 1,0 \\
\hline 16 & BDMN & 1,063 & 0,959 & 0,925 & G & N & N & 1,0 \\
\hline 17 & BEKS & 1,010 & 0,661 & 0,883 & N & N & N & 0,8 \\
\hline 18 & BGTB & 1,072 & 0,925 & 2,135 & G & N & M & 1,4 \\
\hline 19 & BINA & 1,393 & 1,065 & 1,133 & M & G & G & 1,2 \\
\hline 20 & BJBR & 1,065 & 1,172 & 1,136 & G & G & G & 1,1 \\
\hline 21 & BJTM & 1,149 & 1,121 & 0,991 & G & G & N & 1,1 \\
\hline 22 & BMRI & 1,166 & 1,064 & 1,114 & G & G & G & 1,1 \\
\hline 23 & BNBA & 1,283 & 1,161 & 1,096 & M & G & G & 1,2 \\
\hline 24 & BNGA & 1,064 & 1,027 & 0,998 & G & N & N & 1,0 \\
\hline 25 & BNII & 1,020 & 1,100 & 1,049 & N & G & G & 1,1 \\
\hline 26 & BNLI & 1,119 & 0,938 & 0,904 & G & N & N & 1,0 \\
\hline 27 & BSIM & 1,223 & 1,303 & 1,122 & G & M & G & 1,2 \\
\hline 28 & BSKW & 1,895 & 1,238 & 0,945 & M & G & N & 1,4 \\
\hline 29 & BSDW & 1,446 & 1,147 & 0,701 & M & G & N & 1,1 \\
\hline 30 & BTPN & 1,079 & 1,078 & 1,119 & G & G & G & 1,1 \\
\hline 31 & BVIC & 1,117 & 1,077 & 1,122 & G & G & G & 1,1 \\
\hline 32 & DNAR & 1,806 & 1,284 & 1,122 & M & M & G & 1,4 \\
\hline 33 & INPC & 1,111 & 1,072 & 0,988 & G & G & N & 1,1 \\
\hline 34 & MAYA & 1,518 & 1,307 & 1,279 & M & M & M & 1,4 \\
\hline 35 & MCOR & 1,212 & 1,035 & 1,200 & G & N & G & 1,1 \\
\hline 36 & MEGA & 1,004 & 0,964 & 1,039 & N & N & N & 1,0 \\
\hline 37 & NAGA & 1,479 & 1,078 & 1,098 & M & G & G & 1,2 \\
\hline 38 & NOBU & 1,488 & 1,157 & 1,342 & M & G & M & 1,3 \\
\hline 39 & NISP & 1,056 & 1,169 & 1,137 & G & G & G & 1,1 \\
\hline 40 & PNBN & 1,023 & 1,088 & G & N & G & 1,1 \\
\hline 41 & PNBS & 1,608 & 1,222 & 1,131 & M & G & G & 1,7 \\
\hline 42 & SDRA & & & & & G \\
\hline
\end{tabular}

Berdasarkan tabel 10 dapat diketahui angka AQI perusahaan tahun 2014-2016 serta pengelompokkan perusahaan yang tergolong sebagai non manipulator, grey company dan manipulator. Pada tahun 2014, jumlah perusahaan yang tergolong sebagai non manipulator sebanyak 5 perusahaan. Jumlah perusahaan yang tergolong sebagai grey company sebanyak 23 perusahaan. Sedangkan perusahaan yang tergolong sebagai manipulator sebanyak 14 perusahaan

Pada tabel 10 dapat dilihat perhitungan AQI 2015, jumlah perusahaan yang tergolong sebagai non manipulator sebanyak 12 perusahaan. Jumlah perusahaan yang tergolong sebagai grey company sebanyak 23 perusahaan. Sedangkan untuk perusahaan yang tergolong sebagai manipulator sebanyak 7 perusahaan.

Pada tahun 2016, terdapat sebanyak 13 perusahaan yang tergolong sebagai non manipulator. Sebanyak 25 perusahaan tergolong grey company dan 4 perusahaan tergolong sebagai manipulator.

Pada tabel 10 dapat diketahui angka rata-rata AQI perusahaan dari tahun 2014-2016. Perusahaan yang memiliki angka AQI yang $>1$ terdapat 33 perusahaan perbankan. Hal ini menunjukkan bahwa adanya penurunan atas aktiva, namun terdapat peningkatan atas jumlah aktiva tidak lancar. 
Tabel 11

Hasil Perhitungan Sales Growth Index dan Kategori Perusahaan

\begin{tabular}{|c|c|c|c|c|c|c|c|c|}
\hline \multirow{2}{*}{ NO } & \multirow{2}{*}{$\begin{array}{c}\text { KODE } \\
\text { EMITEN }\end{array}$} & \multicolumn{3}{|c|}{ SGI } & \multicolumn{3}{|c|}{ KATEGORI } & \multirow{2}{*}{$\begin{array}{c}\text { HASIL } \\
\text { Rata-rata }\end{array}$} \\
\hline & & 2014 & 2015 & 2016 & 2014 & 2015 & 2016 & \\
\hline 1 & AGRO & 1,423 & 1,315 & 1,379 & $\mathrm{M}$ & $\mathrm{M}$ & $\mathrm{G}$ & 1,3 \\
\hline 2 & AGRS & 1,999 & 1,272 & 0,963 & $\mathrm{M}$ & $M$ & $\mathrm{~N}$ & 1,4 \\
\hline 3 & ARTO & 1,529 & 1,101 & 0,974 & $\mathrm{M}$ & $\mathrm{G}$ & $\mathrm{N}$ & 1,1 \\
\hline 4 & BABP & 1,135 & 1,250 & 1,076 & $\mathrm{G}$ & $\mathrm{G}$ & $\mathrm{G}$ & 1,2 \\
\hline 5 & BACA & 1,419 & 1,421 & 1,164 & $\mathrm{M}$ & $\mathrm{M}$ & $\mathrm{G}$ & 1,3 \\
\hline 6 & BBCA & 1,277 & 1,076 & 1,128 & $\mathrm{M}$ & $\mathrm{G}$ & $\mathrm{G}$ & 1,1 \\
\hline 7 & BBHI & 1,350 & 1,075 & 0,991 & $\mathrm{M}$ & $\mathrm{G}$ & $\mathrm{N}$ & 1,1 \\
\hline 8 & BBKP & 1,192 & 1,171 & 1,103 & $\mathrm{G}$ & $\mathrm{G}$ & G & 1,2 \\
\hline 9 & BBMD & 1,155 & 1,120 & 1,097 & $\mathrm{G}$ & $\mathrm{G}$ & $\mathrm{G}$ & 1,1 \\
\hline 10 & BBNI & 1,276 & 1,093 & 1,191 & $\mathrm{M}$ & $\mathrm{G}$ & $\mathrm{G}$ & 1,2 \\
\hline 11 & BBNP & 1,192 & 0,932 & 0,894 & $\mathrm{G}$ & $\mathrm{N}$ & $\mathrm{N}$ & 1,0 \\
\hline 12 & BBRI & 1,263 & 1,137 & 1,125 & $\mathrm{M}$ & $\mathrm{G}$ & $\mathrm{G}$ & 1,2 \\
\hline 13 & BBTN & 1,188 & 1,169 & 1,231 & $\mathrm{G}$ & $\mathrm{G}$ & $\mathrm{G}$ & 1,2 \\
\hline 14 & BBYB & 1,127 & 1,357 & 1,209 & $\mathrm{G}$ & $\mathrm{M}$ & $\mathrm{M}$ & 1,2 \\
\hline 15 & BCIC & 0,903 & 0,897 & 1,217 & $\mathrm{~N}$ & $\mathrm{~N}$ & $\mathrm{G}$ & 1,0 \\
\hline 16 & BDMN & 1,142 & 0,975 & 0,925 & $\mathrm{G}$ & $\mathrm{N}$ & $\mathrm{N}$ & 1,0 \\
\hline 17 & BEKS & 1,037 & 0,601 & 0,883 & $\mathrm{~N}$ & $\mathrm{~N}$ & $\mathrm{~N}$ & 0,7 \\
\hline 18 & BGTB & 1,040 & 1,100 & 2,135 & $\mathrm{G}$ & $\mathrm{G}$ & $\mathrm{M}$ & 1,2 \\
\hline 19 & BINA & 1,272 & 1,233 & 1,133 & $\mathrm{M}$ & $\mathrm{G}$ & $\mathrm{G}$ & 1,2 \\
\hline 20 & BJBR & 1,081 & 1,141 & 1,136 & $\mathrm{G}$ & $\mathrm{G}$ & $\mathrm{G}$ & 1,1 \\
\hline 21 & BJTM & 1,535 & 1,152 & 0,991 & $\mathrm{M}$ & $\mathrm{G}$ & $\mathrm{G}$ & 1,2 \\
\hline 22 & BMRI & 1,248 & 1,143 & 1,072 & $\mathrm{G}$ & $\mathrm{G}$ & $\mathrm{G}$ & 1,2 \\
\hline 23 & BNBA & 1,337 & 1,244 & 1,086 & $\mathrm{M}$ & $\mathrm{G}$ & $\mathrm{G}$ & 1,2 \\
\hline 24 & BNGA & 1,165 & 1,072 & 0,955 & $\mathrm{G}$ & $\mathrm{G}$ & $\mathrm{N}$ & 1,1 \\
\hline 25 & BNII & 1,228 & 0,964 & 1,048 & $\mathrm{G}$ & $\mathrm{N}$ & $\mathrm{G}$ & 1,1 \\
\hline 26 & BNLI & 1,302 & 1,039 & 0,893 & $\mathrm{M}$ & $\mathrm{N}$ & $\mathrm{N}$ & 1,1 \\
\hline 27 & BSIM & 1,291 & 1,326 & 1,211 & $\mathrm{M}$ & $M$ & $\mathrm{G}$ & 1,3 \\
\hline 28 & BSKW & 2,411 & 1,671 & 1,004 & $\mathrm{M}$ & $M$ & $\mathrm{~N}$ & 1,7 \\
\hline 29 & BSDW & 1,600 & 1,255 & 0,737 & $\mathrm{M}$ & $M$ & $\mathrm{~N}$ & 1,2 \\
\hline 30 & BTPN & 1,123 & 1,058 & 1,053 & $\mathrm{G}$ & $\mathrm{G}$ & $\mathrm{G}$ & 1,1 \\
\hline 31 & BVIC & 1,343 & 0,991 & 1,073 & $\mathrm{M}$ & $\mathrm{N}$ & $\mathrm{G}$ & 1,1 \\
\hline 32 & DNAR & 2,085 & 1,489 & 1,053 & $\mathrm{M}$ & $M$ & $\mathrm{G}$ & 1,5 \\
\hline 33 & INPC & 1,159 & 1,074 & 0,939 & $\mathrm{G}$ & $\mathrm{G}$ & $\mathrm{N}$ & 1,1 \\
\hline 34 & MAYA & 1,581 & 1,399 & 1,196 & $\mathrm{M}$ & $\mathrm{M}$ & $\mathrm{G}$ & 1,4 \\
\hline 35 & MCOR & 1,385 & 1,113 & 1,067 & $\mathrm{M}$ & $\mathrm{G}$ & $\mathrm{G}$ & 1,2 \\
\hline 36 & MEGA & 1,229 & 1,080 & 0,953 & $\mathrm{G}$ & $\mathrm{G}$ & $\mathrm{N}$ & 1,1 \\
\hline 37 & NAGA & 1,602 & 1,419 & 1,012 & $\mathrm{M}$ & $M$ & $\mathrm{~N}$ & 1,3 \\
\hline 38 & NOBU & 2,470 & 1,300 & 1,129 & $\mathrm{M}$ & $\mathrm{M}$ & $\mathrm{G}$ & 1,6 \\
\hline 39 & NISP & 1,286 & 1,166 & 1,107 & $\mathrm{M}$ & $\mathrm{G}$ & $\mathrm{G}$ & 1,2 \\
\hline
\end{tabular}




\begin{tabular}{|l|l|l|l|l|l|l|l|l|}
\hline 40 & PNBN & 1,165 & 1,118 & 1,031 & G & G & N & 1,1 \\
\hline 41 & PNBS & 1,333 & 1,351 & 0,965 & M & M & N & 1,2 \\
\hline 42 & SDRA & 1,103 & 6,161 & 1,145 & G & M & G & 2,8 \\
\hline
\end{tabular}

Berdasarkan tabel 11 perhitungan SGI tahun 2014, dapat diketahui jumlah perusahaan yang tergolong sebagai non manipulator sebanyak 2 perusahaan, grey company sebanyak 17 perusahaan. Sedangkan perusahaan yang tergolong sebagai manipulator sebanyak 23 perusahaan

Pada tabel 11 dapat dilihat perhitungan SGI 2015 jumlah perusahaan yang tergolong sebagai non manipulator sebanyak 7 perusahaan. Jumlah perusahaan yang tergolong sebagai grey company sebanyak 22 perusahaan. Sedangkan perusahaan yang tergolong sebagai manipulator sebanyak 13 perusahaann

Pada tahun 2016, jumlah perusahaan yang tergolong sebagai non manipulator sebanyak 15 perusahaan. Jumlah perusahaan yang tergolong sebagai grey company sebanyak 25 perusahaan. Sedangkan hanya 2 perusahaan yang tergolong sebagai manipulator. Berdasarkan Tabel 11 dapat diketahui angka rata-rata SGI perusahaan dari tahun 2014-2016. Perusahaan yang memiliki angka SGI yang $>1$ terdapat 38 perusahaan perbankan. Hal ini menunjukkan bahwa terjadi peningkatan atas penjualan.

Tabel 12

Hasil Perhitungan Total Accruals to Total Assets dan Kategori Perusahaan

\begin{tabular}{|c|c|c|c|c|c|c|c|c|}
\hline \multirow{2}{*}{ NO } & \multirow{2}{*}{$\begin{array}{c}\text { KODE } \\
\text { EMITEN }\end{array}$} & \multicolumn{3}{|c|}{ TATA } & \multicolumn{3}{|c|}{ KATEGORI } & \multirow{2}{*}{$\begin{array}{c}\text { Hasil } \\
\text { Rata-rata }\end{array}$} \\
\hline & & 2014 & 2015 & 2016 & 2014 & 2015 & 2016 & \\
\hline 1 & AGRO & 0,051 & 0,038 & 0,065 & $\mathrm{M}$ & $\mathrm{M}$ & $\mathrm{M}$ & 0,1 \\
\hline 2 & AGRS & 0,179 & $-0,123$ & $-0,074$ & $\mathrm{M}$ & $\mathrm{N}$ & $\mathrm{N}$ & 0,0 \\
\hline 3 & ARTO & 0,070 & $-0,013$ & $-0,122$ & $\mathrm{M}$ & $\mathrm{N}$ & $\mathrm{N}$ & 0,0 \\
\hline 4 & BABP & $-0,005$ & 0,112 & $-0,007$ & $\mathrm{~N}$ & $\mathrm{M}$ & $\mathrm{N}$ & 0,0 \\
\hline 5 & BACA & 0,087 & 0,104 & $-0,003$ & $\mathrm{M}$ & $M$ & $\mathrm{~N}$ & 0,1 \\
\hline 6 & BBCA & 0,101 & 0,094 & 0,106 & $\mathrm{M}$ & $\mathrm{M}$ & $\mathrm{M}$ & 0,1 \\
\hline 7 & BBHI & 0,025 & $-0,093$ & 0,033 & $\mathrm{G}$ & $\mathrm{N}$ & $\mathrm{M}$ & 0,0 \\
\hline 8 & BBKP & 0,055 & 0,021 & 0,039 & $\mathrm{M}$ & $\mathrm{G}$ & $\mathrm{M}$ & 0,0 \\
\hline 9 & BBMD & 0,067 & 0,040 & 0,032 & $\mathrm{M}$ & $\mathrm{M}$ & $\mathrm{M}$ & 0,0 \\
\hline 10 & BBNI & 0,031 & 0,086 & 0,049 & $\mathrm{M}$ & $\mathrm{M}$ & $\mathrm{M}$ & 0,1 \\
\hline 11 & BBNP & $-0,002$ & $-0,049$ & 0,035 & $\mathrm{~N}$ & $\mathrm{~N}$ & $\mathrm{M}$ & 0,0 \\
\hline 12 & BBRI & 0,144 & 0,097 & 0,073 & $\mathrm{M}$ & $\mathrm{M}$ & $\mathrm{M}$ & 0,1 \\
\hline 13 & BBTN & $-0,003$ & 0,014 & 0,061 & $\mathrm{~N}$ & $\mathrm{~N}$ & $M$ & 0,0 \\
\hline 14 & BBYB & 0,021 & 0,025 & $-0,059$ & $\mathrm{G}$ & $\mathrm{G}$ & $\mathrm{N}$ & 0,0 \\
\hline 15 & BCIC & 0,010 & $-0,171$ & $-0,060$ & $\mathrm{~N}$ & $\mathrm{~N}$ & $\mathrm{~N}$ & $-0,1$ \\
\hline 16 & BDMN & 0,046 & 0,063 & 0,023 & $\mathrm{M}$ & $M$ & $\mathrm{G}$ & 0,0 \\
\hline 17 & BEKS & $-0,018$ & $-0,124$ & $-0,243$ & $\mathrm{~N}$ & $\mathrm{~N}$ & $\mathrm{~N}$ & $-0,1$ \\
\hline 18 & BGTB & 0,086 & $-0,081$ & $-0,074$ & $\mathrm{M}$ & $\mathrm{N}$ & $\mathrm{N}$ & 0,0 \\
\hline 19 & BINA & 0,129 & $-0,040$ & 0,119 & $M$ & $\mathrm{~N}$ & $M$ & 0,1 \\
\hline 20 & BJBR & 0,034 & 0,097 & 0,064 & $M$ & $M$ & $M$ & 0,1 \\
\hline 21 & BJTM & 0,076 & 0,116 & 0,007 & $M$ & $M$ & $\mathrm{~N}$ & 0,1 \\
\hline 22 & BMRI & 0,055 & 0,043 & 0,058 & $\mathrm{M}$ & $\mathrm{M}$ & $M$ & 0,1 \\
\hline
\end{tabular}




\begin{tabular}{|l|l|r|r|r|l|l|l|l|}
\hline 23 & BNBA & 0,099 & 0,029 & 0,072 & M & G & M & 0,1 \\
\hline 24 & BNGA & 0,006 & 0,031 & 0,025 & N & M & G & 0,0 \\
\hline 25 & BNII & $-0,039$ & 0,039 & $-0,013$ & N & M & N & 0,0 \\
\hline 26 & BNLI & 0,043 & 0,011 & $-0,020$ & M & N & N & 0,0 \\
\hline 27 & BSIM & 0,025 & 0,024 & 0,027 & G & G & G & 0,0 \\
\hline 28 & BSKW & 0,100 & $-0,086$ & 0,012 & M & N & N & 0,0 \\
\hline 29 & BSDW & 0,204 & $-0,031$ & 0,098 & M & N & M & 0,1 \\
\hline 30 & BTPN & 0,066 & 0,079 & 0,058 & M & M & M & 0,1 \\
\hline 31 & BVIC & 0,051 & 0,030 & 0,034 & M & G & M & 0,0 \\
\hline 32 & DNAR & 0,108 & 0,101 & $-0,085$ & M & M & N & 0,0 \\
\hline 33 & INPC & 0,023 & 0,065 & $-0,059$ & G & M & N & 0,0 \\
\hline 34 & MAYA & 0,086 & 0,071 & 0,002 & M & M & N & 0,1 \\
\hline 35 & MCOR & 0,072 & $-0,018$ & $-0,037$ & M & N & N & 0,0 \\
\hline 36 & MEGA & $-0,035$ & $-0,053$ & 0,062 & N & N & M & 0,0 \\
\hline 37 & NAGA & 0,193 & $-0,051$ & 0,059 & M & N & M & 0,1 \\
\hline 38 & NOBU & 0,414 & 0,032 & 0,062 & M & M & M & 0,2 \\
\hline 39 & NISP & 0,047 & 0,007 & 0,096 & M & N & M & 0,0 \\
\hline 40 & PNBN & 0,049 & 0,047 & 0,019 & M & M & G & 0,0 \\
\hline 41 & PNBS & $-0,067$ & $-0,016$ & $-0,027$ & N & N & N & 0,0 \\
\hline 42 & SDRA & 0,021 & 0,071 & $-0,020$ & G & M & N & 0,0 \\
\hline
\end{tabular}

Berdasarkan tabel 12 dapat diketahui angka TATA perusahaan dari tahun 2014-2016. Serta pengelompokkan perusahaan yang tergolong sebagai non manipulator, grey company dan manipulator. Pada tahun 2014, jumlah perusahaan yang tergolong sebagai non manipulator sebanyak 9 perusahaan. Jumlah perusahaan yang tergolong sebagai grey company sebanyak 5 perusahaan. Sedangkan perusahaan yang tergolong sebagai manipulator sebanyak 28 perusahaan. Dari perhitungan TATA 2015 jumlah perusahaan yang tergolong sebagai non manipulator sebanyak 17 perusahaan. Jumlah perusahaan yang tergolong sebagai grey company sebanyak 5 perusahaan. Sedangkan perusahaan yang tergolong sebagai manipulator sebanyak 20 perusahaan

Dari perhitungan TATA 2016 dapat diketahui pada tahun 2016 jumlah perusahaan yang tergolong sebagai non manipulator, grey company dan manipulator. Jumlah perusahaan yang tergolong sebagai non manipulator sebanyak 17 perusahaan. Jumlah perusahaan yang tergolong sebagai grey company sebanyak 5 perusahaan. Terdapat sebanyak 20 perusahaan yang tergolong sebagai manipulator. Berdasarkan Tabel 12 dapat diketahui angka ratarataTATA perusahaan dari tahun 2014-2016. Dari 42 perusahaan terdapat 40 perusahaan yang memiliki nilai TATA positif. Hal ini menunjukkan bahwa terdapat peningkatan atas transaksi akrual dalam pengakuan pendapatan

Tabel 13

Hasil Kategori Perusahaan tahun 2014

\begin{tabular}{|c|l|c|c|c|c|c|c|}
\hline NO & KODEEMITEN & DSRI & GMI & AQI & SGI & TATA & HASIL \\
\hline 1 & AGRO & N & M & G & M & M & M \\
\hline 2 & AGRS & N & M & M & M & M & M \\
\hline 3 & ARTO & N & M & M & M & M & M \\
\hline 4 & BABP & N & M & G & G & N & G \\
\hline
\end{tabular}




\begin{tabular}{|c|c|c|c|c|c|c|c|}
\hline 5 & BACA & $\mathrm{N}$ & $\mathrm{M}$ & $\mathrm{M}$ & $\mathrm{M}$ & $\mathrm{M}$ & $\mathrm{M}$ \\
\hline 6 & BBCA & $\mathrm{N}$ & $\mathrm{G}$ & $\mathrm{G}$ & $\mathrm{M}$ & $\mathrm{M}$ & $\mathrm{M}$ \\
\hline 7 & BBHI & $\mathrm{N}$ & $\mathrm{M}$ & $\mathrm{G}$ & $\mathrm{M}$ & $\mathrm{G}$ & $\mathrm{M}$ \\
\hline 8 & BBKP & $\mathrm{N}$ & $\mathrm{G}$ & $\mathrm{G}$ & $\mathrm{G}$ & $\mathrm{M}$ & $\mathrm{G}$ \\
\hline 9 & BBMD & $\mathrm{N}$ & $\mathrm{G}$ & $\mathrm{G}$ & $\mathrm{G}$ & $\mathrm{M}$ & $\mathrm{G}$ \\
\hline 10 & BBNI & $\mathrm{N}$ & $\mathrm{G}$ & $\mathrm{G}$ & $M$ & $\mathrm{M}$ & $\mathrm{M}$ \\
\hline 11 & BBNP & $\mathrm{N}$ & $\mathrm{G}$ & $\mathrm{N}$ & $\mathrm{G}$ & $\mathrm{N}$ & $\mathrm{G}$ \\
\hline 12 & BBRI & $\mathrm{N}$ & $\mathrm{G}$ & $\mathrm{M}$ & $\mathrm{M}$ & $\mathrm{M}$ & $\mathrm{M}$ \\
\hline 13 & BBTN & $\mathrm{N}$ & $\mathrm{M}$ & $\mathrm{G}$ & $\mathrm{G}$ & $\mathrm{N}$ & $\mathrm{G}$ \\
\hline 14 & BBYB & $\mathrm{G}$ & $\mathrm{G}$ & $\mathrm{G}$ & $\mathrm{G}$ & $\mathrm{G}$ & $\mathrm{G}$ \\
\hline 15 & $\mathrm{BCIC}$ & $\mathrm{N}$ & $\mathrm{M}$ & $\mathrm{N}$ & $\mathrm{N}$ & $\mathrm{N}$ & $\mathrm{N}$ \\
\hline 16 & BDMN & $\mathrm{N}$ & $\mathrm{G}$ & $\mathrm{G}$ & $\mathrm{G}$ & $\mathrm{M}$ & $\mathrm{G}$ \\
\hline 17 & BEKS & $\mathrm{N}$ & $\mathrm{M}$ & $\mathrm{N}$ & $\mathrm{N}$ & $\mathrm{N}$ & $\mathrm{N}$ \\
\hline 18 & BGTB & $\mathrm{N}$ & $\mathrm{M}$ & $\mathrm{G}$ & $\mathrm{G}$ & $\mathrm{M}$ & $\mathrm{M}$ \\
\hline 19 & BINA & $\mathrm{N}$ & $\mathrm{N}$ & $\mathrm{M}$ & $M$ & $\mathrm{M}$ & $\mathrm{M}$ \\
\hline 20 & BJBR & $\mathrm{N}$ & $\mathrm{G}$ & $\mathrm{G}$ & $\mathrm{G}$ & $\mathrm{M}$ & $\mathrm{G}$ \\
\hline 21 & BJTM & $\mathrm{N}$ & $\mathrm{M}$ & $\mathrm{G}$ & $\mathrm{M}$ & $\mathrm{M}$ & $\mathrm{M}$ \\
\hline 22 & BMRI & $\mathrm{M}$ & $\mathrm{G}$ & $\mathrm{G}$ & $\mathrm{G}$ & $\mathrm{M}$ & $\mathrm{G}$ \\
\hline 23 & BNBA & $\mathrm{M}$ & $\mathrm{M}$ & $\mathrm{M}$ & $M$ & $\mathrm{M}$ & $\mathrm{M}$ \\
\hline 24 & BNGA & $\mathrm{M}$ & $\mathrm{G}$ & $\mathrm{G}$ & $\mathrm{G}$ & $\mathrm{N}$ & $\mathrm{G}$ \\
\hline 25 & BNII & $\mathrm{M}$ & $\mathrm{G}$ & $\mathrm{N}$ & $\mathrm{G}$ & $\mathrm{N}$ & $\mathrm{G}$ \\
\hline 26 & BNLI & $\mathrm{M}$ & $\mathrm{M}$ & $\mathrm{G}$ & $\mathrm{M}$ & $\mathrm{M}$ & $\mathrm{M}$ \\
\hline 27 & BSIM & $\mathrm{M}$ & $\mathrm{G}$ & $\mathrm{G}$ & $\mathrm{M}$ & $\mathrm{G}$ & $\mathrm{G}$ \\
\hline 28 & BSKW & $\mathrm{M}$ & $\mathrm{M}$ & $\mathrm{M}$ & $\mathrm{M}$ & $\mathrm{M}$ & $\mathrm{M}$ \\
\hline 29 & BSDW & $\mathrm{M}$ & $\mathrm{M}$ & $\mathrm{M}$ & $\mathrm{M}$ & $\mathrm{M}$ & $\mathrm{M}$ \\
\hline 30 & BTPN & $\mathrm{M}$ & $\mathrm{G}$ & $\mathrm{G}$ & $\mathrm{G}$ & $\mathrm{M}$ & $\mathrm{G}$ \\
\hline 31 & BVIC & $\mathrm{M}$ & $\mathrm{M}$ & $\mathrm{G}$ & $\mathrm{M}$ & $\mathrm{M}$ & $\mathrm{M}$ \\
\hline 32 & DNAR & $\mathrm{M}$ & $\mathrm{M}$ & $\mathrm{M}$ & $M$ & $\mathrm{M}$ & $\mathrm{M}$ \\
\hline 33 & INPC & $\mathrm{M}$ & $\mathrm{M}$ & $\mathrm{G}$ & $\mathrm{G}$ & $\mathrm{G}$ & $\mathrm{G}$ \\
\hline 34 & MAYA & $\mathrm{M}$ & $\mathrm{M}$ & $\mathrm{M}$ & $\mathrm{M}$ & $\mathrm{M}$ & $\mathrm{M}$ \\
\hline 35 & MCOR & $\mathrm{M}$ & $\mathrm{M}$ & $\mathrm{G}$ & $\mathrm{M}$ & $\mathrm{M}$ & $\mathrm{M}$ \\
\hline 36 & MEGA & $\mathrm{M}$ & $\mathrm{M}$ & $\mathrm{N}$ & $\mathrm{G}$ & $\mathrm{N}$ & $\mathrm{G}$ \\
\hline 37 & NAGA & $\mathrm{M}$ & $\mathrm{M}$ & $\mathrm{M}$ & $\mathrm{M}$ & $\mathrm{M}$ & $\mathrm{M}$ \\
\hline 38 & NOBU & $\mathrm{M}$ & $\mathrm{G}$ & $\mathrm{M}$ & $\mathrm{M}$ & $\mathrm{M}$ & $\mathrm{M}$ \\
\hline 39 & NISP & $\mathrm{M}$ & $\mathrm{G}$ & $\mathrm{G}$ & $\mathrm{M}$ & $\mathrm{M}$ & $\mathrm{M}$ \\
\hline 40 & PNBN & $\mathrm{M}$ & $\mathrm{G}$ & $\mathrm{G}$ & $\mathrm{G}$ & $\mathrm{M}$ & $\mathrm{G}$ \\
\hline 41 & PNBS & $\mathrm{M}$ & $\mathrm{N}$ & $\mathrm{M}$ & $\mathrm{M}$ & $\mathrm{N}$ & $\mathrm{M}$ \\
\hline 42 & SDRA & $\mathrm{M}$ & $\mathrm{N}$ & $\mathrm{M}$ & $\mathrm{G}$ & $\mathrm{G}$ & $\mathrm{M}$ \\
\hline
\end{tabular}

Berdasarkan tabel 13 diketahui pada tahun 2014 dari jumlah total 42 perusahaan perbankan terdapat sebanyak 2 perusahaan yang tergolong sebagai non manipulator. Hal ini menunjukkan perusahaan telah mampu menyajikan laporan keuangan yang tidak menyesatkan para pemangku kepentingan. Serta diketahui dari hasil pengelompokkan terdapat sebanyak 16 perusahaan yang tergolong sebagai grey manipulator. Hal ini menunjukkan bahwa perusahaan memiliki indikasi untuk melakukan kecurangan laporan keuangan. Selain itu, terdapat 
sebanyak 24 perusahaan yang tergolong sebagai manipulator. Hal ini menandakan bahwa terdapat indikasi kecurangan terhadap laporan keungan perusahaan.

Tabel 14

Hasil Kategori Perusahaan tahun 2015

\begin{tabular}{|c|c|c|c|c|c|c|c|}
\hline NO & KODE EMITEN & DSRI & GMI & AQI & SGI & TATA & HASIL \\
\hline 1 & AGRO & $\mathrm{N}$ & $\mathrm{N}$ & $\mathrm{M}$ & $\mathrm{M}$ & $\mathrm{M}$ & $\mathrm{M}$ \\
\hline 2 & AGRS & $\mathrm{N}$ & $\mathrm{N}$ & $\mathrm{N}$ & $\mathrm{M}$ & $\mathrm{N}$ & $\mathrm{N}$ \\
\hline 3 & ARTO & $\mathrm{N}$ & $\mathrm{N}$ & $\mathrm{N}$ & $\mathrm{G}$ & $\mathrm{N}$ & $\mathrm{N}$ \\
\hline 4 & $\mathrm{BABP}$ & $\mathrm{N}$ & $\mathrm{N}$ & $\mathrm{M}$ & $\mathrm{G}$ & $\mathrm{M}$ & $\mathrm{G}$ \\
\hline 5 & BACA & $\mathrm{N}$ & $\mathrm{G}$ & $\mathrm{M}$ & $M$ & $\mathrm{M}$ & $M$ \\
\hline 6 & $\mathrm{BBCA}$ & $\mathrm{G}$ & $\mathrm{N}$ & $\mathrm{G}$ & $\mathrm{G}$ & $\mathrm{M}$ & $\mathrm{G}$ \\
\hline 7 & $\mathrm{BBHI}$ & $\mathrm{N}$ & $\mathrm{N}$ & $\mathrm{N}$ & $\mathrm{G}$ & $\mathrm{N}$ & $\mathrm{N}$ \\
\hline 8 & BBKP & $\mathrm{N}$ & $\mathrm{N}$ & $\mathrm{G}$ & $\mathrm{G}$ & $\mathrm{G}$ & $\mathrm{G}$ \\
\hline 9 & BBMD & $\mathrm{N}$ & $\mathrm{N}$ & $\mathrm{G}$ & $\mathrm{G}$ & $\mathrm{M}$ & $\mathrm{G}$ \\
\hline 10 & BBNI & $\mathrm{G}$ & $\mathrm{N}$ & $\mathrm{G}$ & $\mathrm{G}$ & $\mathrm{M}$ & $\mathrm{G}$ \\
\hline 11 & BBNP & $\mathrm{G}$ & $\mathrm{N}$ & $\mathrm{N}$ & $\mathrm{N}$ & $\mathrm{N}$ & $\mathrm{N}$ \\
\hline 12 & BBRI & $\mathrm{N}$ & $\mathrm{N}$ & $\mathrm{G}$ & $\mathrm{G}$ & $\mathrm{M}$ & $\mathrm{G}$ \\
\hline 13 & BBTN & $\mathrm{N}$ & $\mathrm{N}$ & $\mathrm{G}$ & $\mathrm{G}$ & $\mathrm{N}$ & $\mathrm{N}$ \\
\hline 14 & BBYB & $\mathrm{N}$ & $\mathrm{N}$ & $\mathrm{M}$ & $\mathrm{M}$ & $\mathrm{G}$ & $\mathrm{G}$ \\
\hline 15 & BCIC & $\mathrm{G}$ & $\mathrm{N}$ & $\mathrm{G}$ & $\mathrm{N}$ & $\mathrm{N}$ & $\mathrm{N}$ \\
\hline 16 & BDMN & $\mathrm{N}$ & $\mathrm{N}$ & $\mathrm{N}$ & $\mathrm{N}$ & $\mathrm{M}$ & $\mathrm{N}$ \\
\hline 17 & BEKS & $\mathrm{G}$ & $\mathrm{M}$ & $\mathrm{N}$ & $\mathrm{N}$ & $\mathrm{N}$ & $\mathrm{N}$ \\
\hline 18 & BGTB & $\mathrm{N}$ & $\mathrm{N}$ & $\mathrm{N}$ & $\mathrm{G}$ & $\mathrm{N}$ & $\mathrm{N}$ \\
\hline 19 & BINA & $\mathrm{N}$ & $\mathrm{G}$ & $\mathrm{G}$ & $\mathrm{G}$ & $\mathrm{N}$ & $\mathrm{G}$ \\
\hline 20 & BJBR & $\mathrm{N}$ & $\mathrm{N}$ & $\mathrm{G}$ & $\mathrm{G}$ & $M$ & $\mathrm{G}$ \\
\hline 21 & BJTM & $\mathrm{N}$ & $\mathrm{G}$ & $\mathrm{G}$ & $\mathrm{G}$ & $\mathrm{M}$ & $\mathrm{G}$ \\
\hline 22 & BMRI & $\mathrm{N}$ & $\mathrm{N}$ & G & $\mathrm{G}$ & $\mathrm{M}$ & G \\
\hline 23 & BNBA & $\mathrm{N}$ & $\mathrm{G}$ & $\mathrm{G}$ & $\mathrm{G}$ & $\mathrm{G}$ & $\mathrm{G}$ \\
\hline 24 & BNGA & $\mathrm{N}$ & $\mathrm{N}$ & $\mathrm{N}$ & $\mathrm{G}$ & $\mathrm{M}$ & $\mathrm{N}$ \\
\hline 25 & BNII & $\mathrm{G}$ & $\mathrm{N}$ & $\mathrm{G}$ & $\mathrm{N}$ & $\mathrm{M}$ & $\mathrm{G}$ \\
\hline 26 & BNLI & $\mathrm{N}$ & $\mathrm{N}$ & $\mathrm{N}$ & $\mathrm{N}$ & $\mathrm{N}$ & $\mathrm{N}$ \\
\hline 27 & BSIM & $\mathrm{N}$ & $\mathrm{N}$ & $\mathrm{M}$ & $\mathrm{M}$ & $\mathrm{G}$ & $\mathrm{G}$ \\
\hline 28 & BSKW & $\mathrm{N}$ & $\mathrm{N}$ & $\mathrm{G}$ & $\mathrm{M}$ & $\mathrm{N}$ & $\mathrm{N}$ \\
\hline 29 & BSDW & $\mathrm{N}$ & $\mathrm{G}$ & $\mathrm{G}$ & $\mathrm{M}$ & $\mathrm{N}$ & $\mathrm{G}$ \\
\hline 30 & BTPN & $\mathrm{G}$ & $\mathrm{N}$ & $\mathrm{G}$ & $\mathrm{G}$ & $\mathrm{M}$ & $\mathrm{G}$ \\
\hline 31 & BVIC & G & $\mathrm{N}$ & G & $\mathrm{N}$ & G & G \\
\hline 32 & DNAR & $\mathrm{N}$ & $\mathrm{N}$ & $\mathrm{M}$ & $\mathrm{M}$ & $\mathrm{M}$ & $\mathrm{G}$ \\
\hline 33 & INPC & $\mathrm{N}$ & $\mathrm{N}$ & $\mathrm{G}$ & $\mathrm{G}$ & $\mathrm{M}$ & $\mathrm{G}$ \\
\hline 34 & MAYA & $\mathrm{N}$ & $\mathrm{N}$ & $\mathrm{M}$ & $\mathrm{M}$ & $\mathrm{M}$ & $\mathrm{M}$ \\
\hline 35 & MCOR & $\mathrm{N}$ & $\mathrm{N}$ & $\mathrm{N}$ & $\mathrm{G}$ & $\mathrm{N}$ & $\mathrm{N}$ \\
\hline 36 & MEGA & $\mathrm{N}$ & $\mathrm{N}$ & $\mathrm{N}$ & $\mathrm{G}$ & $\mathrm{N}$ & $\mathrm{N}$ \\
\hline 37 & NAGA & $\mathrm{N}$ & $\mathrm{N}$ & $\mathrm{G}$ & $\mathrm{M}$ & $\mathrm{N}$ & $\mathrm{N}$ \\
\hline 38 & NOBU & $\mathrm{G}$ & $\mathrm{N}$ & $\mathrm{G}$ & $\mathrm{M}$ & $\mathrm{M}$ & $\mathrm{M}$ \\
\hline
\end{tabular}




\begin{tabular}{|l|l|c|c|c|c|c|c|}
\hline 39 & NISP & G & N & G & G & N & G \\
\hline 40 & PNBN & N & N & N & G & M & N \\
\hline 41 & PNBS & N & M & G & M & N & G \\
\hline 42 & SDRA & N & M & G & M & M & M \\
\hline
\end{tabular}

Berdasarkan tabel 14 diketahui bahwa pada tahun 2015 dari jumlah total 42 perusahaan perbankan terdapat sebanyak 16 perusahaan yang tergolong sebagai non manipulator. Hal ini menunjukkan perusahaan telah mampu menyajikan laporan keuangan yang tidak menyesatkan para pemangku kepentingan. Serta diketahui dari hasil pengelompokkan terdapat sebanyak 21 perusahaan yang tergolong sebagai grey manipulator, hal ini menunjukkan bahwa perusahaan memiliki indikasi untuk melakukan kecurangan laporan keuangan. Selain itu, terdapat sebanyak 5 perusahaan yang tergolong sebagai manipulator, hal ini menandakan bahwa terdapat indikasi kecurangan terhadap laporan keungan perusahaan

Tabel 13

Hasil Kategori Perusahaan tahun 2016

\begin{tabular}{|c|c|c|c|c|c|c|c|}
\hline NO & $\begin{array}{c}\text { KODE } \\
\text { EMITEN }\end{array}$ & DSRI & GMI & AQI & SGI & TATA & HASIL \\
\hline 1 & AGRO & $\mathrm{G}$ & $\mathrm{N}$ & $\mathrm{M}$ & $\mathrm{G}$ & $\mathrm{M}$ & $\mathrm{M}$ \\
\hline 2 & AGRS & G & $\mathrm{N}$ & $\mathrm{N}$ & $\mathrm{N}$ & $\mathrm{N}$ & $\mathrm{N}$ \\
\hline 3 & ARTO & $\mathrm{G}$ & $\mathrm{N}$ & $\mathrm{N}$ & $\mathrm{N}$ & $\mathrm{N}$ & $\mathrm{N}$ \\
\hline 4 & BABP & $\mathrm{N}$ & $\mathrm{N}$ & $\mathrm{G}$ & $\mathrm{G}$ & $\mathrm{N}$ & $\mathrm{N}$ \\
\hline 5 & BACA & $\mathrm{N}$ & $\mathrm{N}$ & $\mathrm{G}$ & $\mathrm{G}$ & $\mathrm{N}$ & $\mathrm{N}$ \\
\hline 6 & BBCA & $\mathrm{N}$ & $\mathrm{N}$ & $\mathrm{G}$ & $\mathrm{G}$ & $\mathrm{M}$ & $\mathrm{G}$ \\
\hline 7 & BBHI & $\mathrm{G}$ & $\mathrm{N}$ & $\mathrm{N}$ & $\mathrm{N}$ & $\mathrm{M}$ & $\mathrm{N}$ \\
\hline 8 & BBKP & $\mathrm{N}$ & $\mathrm{N}$ & $\mathrm{G}$ & $\mathrm{G}$ & M & $\mathrm{G}$ \\
\hline 9 & BBMD & $\mathrm{N}$ & $\mathrm{N}$ & $\mathrm{G}$ & $\mathrm{G}$ & $\mathrm{M}$ & $\mathrm{G}$ \\
\hline 10 & BBNI & $\mathrm{N}$ & $\mathrm{N}$ & $\mathrm{G}$ & $\mathrm{G}$ & $\mathrm{M}$ & $\mathrm{G}$ \\
\hline 11 & BBNP & $\mathrm{N}$ & $\mathrm{N}$ & $\mathrm{N}$ & $\mathrm{N}$ & $\mathrm{M}$ & $\mathrm{N}$ \\
\hline 12 & BBRI & $\mathrm{N}$ & $\mathrm{N}$ & $\mathrm{G}$ & $\mathrm{G}$ & $\mathrm{M}$ & $\mathrm{G}$ \\
\hline 13 & BBTN & $\mathrm{G}$ & $\mathrm{N}$ & $\mathrm{G}$ & $\mathrm{G}$ & $\mathrm{M}$ & $\mathrm{G}$ \\
\hline 14 & BBYB & $\mathrm{N}$ & $\mathrm{N}$ & $\mathrm{G}$ & $\mathrm{M}$ & $\mathrm{N}$ & $\mathrm{N}$ \\
\hline 15 & BCIC & $\mathrm{N}$ & $\mathrm{N}$ & $\mathrm{G}$ & $\mathrm{G}$ & $\mathrm{N}$ & $\mathrm{N}$ \\
\hline 16 & BDMN & $\mathrm{N}$ & $\mathrm{N}$ & $\mathrm{N}$ & $\mathrm{N}$ & $\mathrm{G}$ & $\mathrm{N}$ \\
\hline 17 & BEKS & $\mathrm{M}$ & $\mathrm{M}$ & $\mathrm{N}$ & $\mathrm{N}$ & $\mathrm{N}$ & $\mathrm{N}$ \\
\hline 18 & BGTB & $\mathrm{G}$ & $\mathrm{N}$ & $\mathrm{M}$ & $\mathrm{M}$ & $\mathrm{N}$ & $\mathrm{M}$ \\
\hline 19 & BINA & $\mathrm{N}$ & $\mathrm{N}$ & $\mathrm{G}$ & $\mathrm{G}$ & $\mathrm{M}$ & $\mathrm{G}$ \\
\hline 20 & BJBR & $\mathrm{G}$ & $\mathrm{N}$ & $\mathrm{G}$ & $\mathrm{G}$ & $\mathrm{M}$ & $\mathrm{G}$ \\
\hline 21 & BJTM & $\mathrm{N}$ & $\mathrm{N}$ & $\mathrm{N}$ & $\mathrm{G}$ & $\mathrm{N}$ & $\mathrm{N}$ \\
\hline 22 & BMRI & $\mathrm{N}$ & $\mathrm{N}$ & $\mathrm{G}$ & $\mathrm{G}$ & $\mathrm{M}$ & $\mathrm{G}$ \\
\hline 23 & BNBA & $\mathrm{N}$ & $\mathrm{N}$ & $\mathrm{G}$ & $\mathrm{G}$ & $\mathrm{M}$ & $\mathrm{G}$ \\
\hline 24 & BNGA & $\mathrm{G}$ & $\mathrm{N}$ & $\mathrm{N}$ & $\mathrm{N}$ & $\mathrm{G}$ & $\mathrm{N}$ \\
\hline 25 & BNII & $\mathrm{N}$ & $\mathrm{N}$ & $\mathrm{G}$ & $\mathrm{G}$ & $\mathrm{N}$ & $\mathrm{N}$ \\
\hline 26 & BNLI & $\mathrm{N}$ & $\mathrm{N}$ & $\mathrm{N}$ & $\mathrm{N}$ & $\mathrm{N}$ & $\mathrm{N}$ \\
\hline 27 & BSIM & $\mathrm{N}$ & $\mathrm{N}$ & $\mathrm{G}$ & $\mathrm{G}$ & $\mathrm{G}$ & $\mathrm{G}$ \\
\hline
\end{tabular}




\begin{tabular}{|c|l|c|c|c|c|c|c|}
\hline 28 & BSKW & N & M & N & N & N & N \\
\hline 29 & BSDW & N & N & N & N & M & N \\
\hline 30 & BTPN & N & N & G & G & M & G \\
\hline 31 & BVIC & G & M & G & G & M & M \\
\hline 32 & DNAR & G & N & G & G & N & G \\
\hline 33 & INPC & G & N & N & N & N & N \\
\hline 34 & MAYA & G & N & M & G & N & G \\
\hline 35 & MCOR & N & N & N & N & M & N \\
\hline 36 & MEGA & N & N & G & N & M & N \\
\hline 37 & NAGA & N & N & M & G & M & G \\
\hline 38 & NOBU & N & N & G & G & M & G \\
\hline 39 & NISP & N & N & G & N & G & N \\
\hline 40 & PNBN & G & M & G & N & N & G \\
\hline 41 & PNBS & G & N & G & G & N & G \\
\hline 42 & SDRA & & & & & & \\
\hline
\end{tabular}

Berdasarkan Tabel19 hasil kategori perusahaan, dapat diketahui bahwa sebanyak 20 perusahaan yang tergolong sebagai non manipulator, hal ini menunjukkan perusahaan telah mampu menyajikan laporan keuangan yang tidak menyesatkan para pemangku kepentingan. Serta diketahui dari hasil pengelompokkan terdapat sebanyak 19 perusahaan yang tergolong sebagai grey manipulator, hal ini menunjukkan bahwa perusahaan memiliki indikasi untuk melakukan kecurangan laporan keuangan. Selain itu, terdapat sebanyak 3 perusahaan yang tergolong sebagai manipulator, hal ini menandakan bahwa terdapat indikasi kecurangan terhadap laporan keungan perusahaan.

\section{Perhitungan Persentase Perusahaan}

1 Perusahaan Non Manipulator

a) Perusahaan Non Manipulator tahun 2014

$$
\frac{2}{42} \times 100 \%=4,76 \%
$$

b) Perusahaan Non Manipulator tahun 2015

$$
\frac{16}{42} \times 100 \%=38,1 \%
$$

c) Perusahaan Non Manipulator tahun 2016

$$
\frac{20}{42} \times 100 \%=47,6 \%
$$

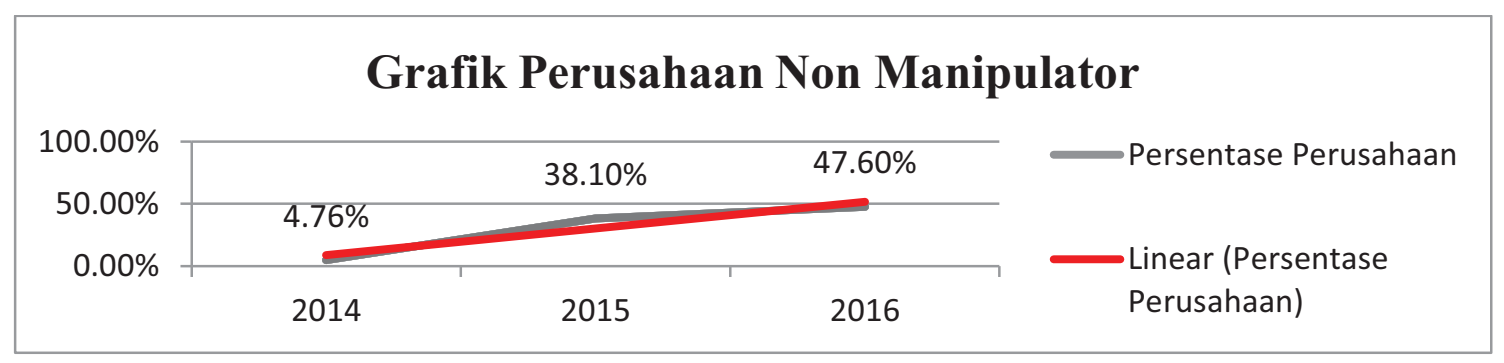

Grafik 1.Perusahaan nonmanipulator 
Analisis dengan menggunakan index parameter Beneish M-Score yang dilakukan terhadap 42 perusahaan perbankan yang terdaftar di Bursa Efek Indonesia 2014-2016. Menyatakan bahwa pada tahun 2014 terdapat 2 perusahaan yang tergolong sebagai non manipulator. Pada tahun 2015 terdapat 16 perusahaan yang tergolong sebagai non manipulator dan pada tahun 2016 terdapat 20 perusahaan yang tergolong sebagai non manipulator.

Berdasarkan perhitungan persentase yang digambarkan pada Grafik 1menunjukkan pada tahun 2014 persentase perusahaan perbankan yang tergolong sebagai non manipulator sebesar 4,76\%. Pada tahun 2015, persentase tersebut mengalami peningkatan sebesar $38,1 \%$ yang diikuti dengan adanya peningkatan jumlah perusahaan yang tergolong sebagai non manipulator. Pada tahun 2016, persentase mengalami peningkatan sebesar 47,6\%. Sehingga, tren yang muncul adalah adanya peningkatan persentase perusahaan yang tergolong sebagai non manipulator.

\section{Perusahaan Grey Company}

a) Perusahaan Grey Company tahun 2014

$$
\frac{16}{42} \times 100 \%=38,1 \%
$$

b) Perusahaan Grey Company tahun 2015

$$
\frac{21}{42} \times 100 \%=50 \%
$$

c) Perusahaan Grey Company tahun 2016

$$
\frac{19}{42} \times 100 \%=45,2 \%
$$

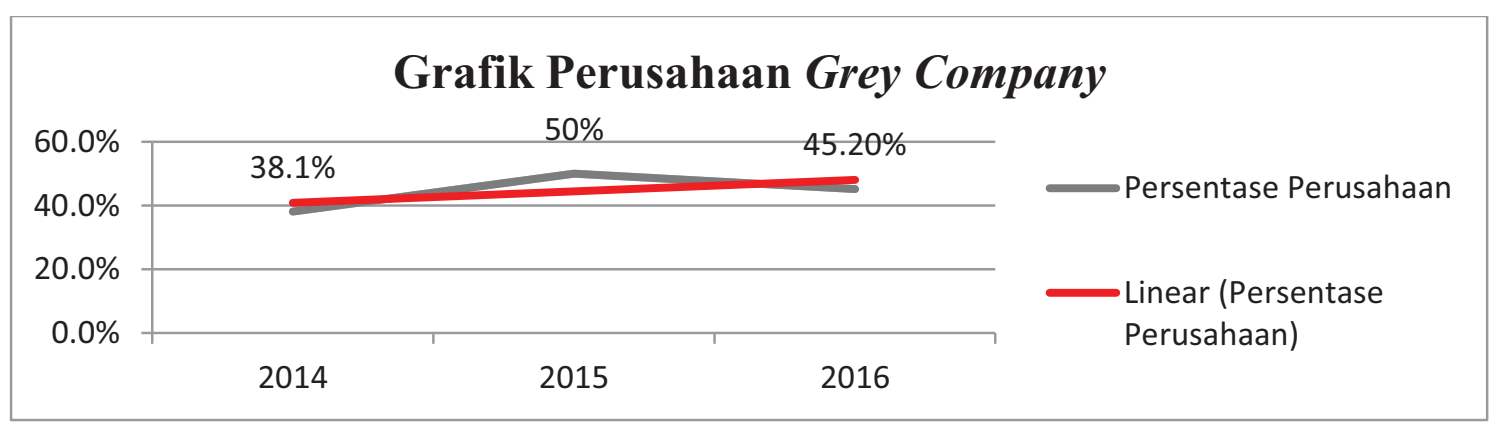

Grafik. 2 Grafik Perusahaan Grey Company

Berdasarkan hasil pengolahan data menggunakan lima index parameter Beneish M-Score yang dilakukan pada 42 perusahaan perbankan selama tahun 2014-2016. Diperoleh sebanyak 16 perusahaan pada tahun 2014 yang tergolong sebagai grey company. Tahun 2015, terdapat 21 perusahaan yang tergolong sebagai grey company sedangkan pada tahun 2016 jumlah perusahaan yang tergolong sebagai non manipulator sebanyak 19 perusahaan. Perusahaan yang tergolong sebagai grey company merupakan perusahaan yang tidak tergolong sebagai non manipulator maupun manipulator.

Berdasarkan perhitungan persentase yang digambarkan pada Grafik 2 menunjukkan pada tahun 2014 persentase perusahaan perbankan yang tergolong sebagai grey company sebesar $38,1 \%$. Pada tahun 2015, persentase tersebut mengalami peningkatan sebesar 50\% yang diikuti dengan adanya peningkatan jumlah perusahaan yang tergolong sebagai grey company. Pada tahun 2016 , persentase mengalami penurunan sebesar $45,2 \%$. Sehingga, tren yang muncul yaitu mengalami peningkatan. 


\section{Perusahaan Manipulator}

a) Perusahaan Manipulator tahun 2014

$$
\frac{24}{42} \times 100 \%=57,1 \%
$$

b) Perusahaan Manipulator tahun 2015

$$
\frac{5}{42} \times 100 \%=11,9 \%
$$

c) Perusahaan Manipulator tahun 2016

$$
\frac{3}{42} \times 100 \%=7,14 \%
$$

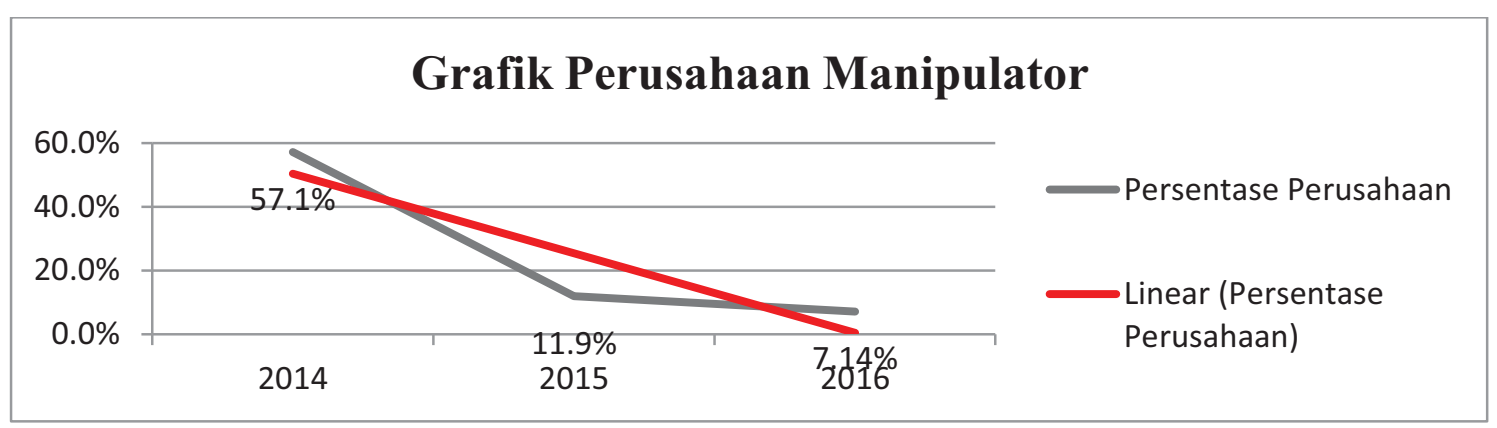

\section{Grafik. 3 Grafik Perusahaan Manipulator}

Berdasarkan hasil perhitungan data dengan menggunakan lima index parameter Beneish M-Score yang dilakukan pada 42 perusahaan perbankan selama tahun 2014-2016. Diperoleh jumlah perusahaan yang tergolong sebagai manipulators. Pada tahun 2014 jumlah perusahaan yang tergolong sebagai manipulator terdapat sebanyak 24 perusahaan, tahun 2015 terdapat 5 perusahaan dan pada tahun 2016 jumlahnya mengalami penurunan yaitu sebanyak 3 perusahaan. Pada Grafik 3 menunjukkan persentase perusahaan selama tahun 2014-2016. Pada tahun 2014 persentase perusahaan sebesar 57,1\%. Pada tahun 2015 persentase 11,9\%. Pada tahun 2016 persentase perusahaan mengalami penurunan sebesar 7,14\%. Sehingga, tren yang muncul selama 3 tahun mengalami penurunan yang signifikan.

\section{SIMPULAN, KETERBATASAN DAN IMPLIKASI PENELITIAN}

\section{SIMPULAN}

\section{Perusahaan Non Manipulator}

Berdasarkan analisis manipulasi laporan keuangan dengan menggunakan beneish ratio index yang dilakukan terhadap 42 perusahaan perbankan yang terdaftar di BEI tahun 20142016. Pada tahun 2014 diperoleh hasil bahwa terdapat 2 perusahaan yang tergolong sebagai non manipulator, tahun 2015 terdapat 16 perusahaan dan pada tahun 2016 terdapat 20 perusahaan yang tergolong sebagai non manipulator dan tidak ada indikasi bahwa perusahaan melakukan manipulasi terhadap laporan keuangan. Selama tiga tahun perusahaan yang tergolong sebagai non manipulator mengalami peningkatan hal ini menandakan bahwa pada perusahaan perbankan di Indonesia telah mampu menyajikan laporan keuangan yang bebas dari adanya manipulasi. 


\section{Perusahaan Grey Company}

Berdasarkan analisis manipulasi laporan keuangan dengan menggunakan beneish ratio index yang dilakukan terhadap 42 perusahaan perbankan yang terdaftar di BEI tahun 20142016 dihasilkan pada tahun 2014 terdapat 16 perusahaan yang tergolong sebagai grey company, tahun 2015 terdapat 21 perusahaan dan pada tahun 2016 terdapat 19 perusahaan yang tergolong sebagai grey company. Hal ini menandakan bahwa pada perusahaan tersebut memiliki potensi untuk melakukan melakukan manipulasi terhadap laporan keuangan, meskipun potensi yang muncul tidaklah signifikan.

\section{Perusahaan Manipulator}

Berdasarkan analisis manipulasi laporan keuangan dengan menggunakan beneish ratio index yang dilakukan terhadap 42 perusahaan perbankan yang terdaftar di BEI tahun 20142016. Dihasilkan pada tahun 2014 terdapat 24 perusahaan yang tergolong sebagai manipulator, tahun 2015 terdapat 5 perusahaan dan pada tahun 2016 terdapat 3 perusahaan yang tergolong sebegai manipulator. Hal ini menandakan bahwa pada perusahaan tersebut terdapat indikasi melakukan kecurangan laporan keuangan. Namun, jika dilihat selama tahun 2014-2016 jumlah perusahaan yang tergolong sebagai manipulator mengalami penurunan dari tahun ketahun. Hal ini menunjukkan bahwa tingkat indikasi kecurangan terhadap perusahaan perbankan telah mampu ditekan seminimal mungkin.

\section{KETERBATASAN PENELITIAN}

Keterbatasan pada penelitian ini adalah hanya menerapkan beneish model score sebagai acuan untuk melakukan pengelmpokkan perusahaan perbankan yang tergolong sebagai non manipulator, grey company dan manipulator serta tidak melakukan penelusuran lebih lanjut terhada fraud yang terjadi di dalam perusahaan perbankan

\section{IMPLIKASI PENELITIAN}

Penelitian ini menunjukkan alat analisis dalam pendeteksian kecurangan laporan keuangan dengan menggunakan indeks ratio beneish. Hasil penelitian memnunjukkan bahwa sepanjang tiga tahun jumlah non manipulator mengalami peningkatan, hal ini berbanding terbalik dengan jumlah penurunan perusahaan yang tergolong sebagai manipulator mengalami penurunan sedangkan jumlah perusahaan yang tergolong sebagai grey company mengalami kenaikan meskipun kenaikan yang terjadi tidaklah signifikan. Implikasi pada penelitian ini adalah memberikan sumbangan pemikiran serta bahan pertimbangan bagi para pemngku kepentingan dalam membuat keputusan ekonomi.

Jika perusahaan perbankan terindikasi melakukan kecurangan maka investor akan meningkatkan risiko pengembalian terhadap investasi yang telah ditanamnya kepada masingmasing perusahaan. Bagi kreditor dampak yang dapat terjadi adalah meningkatnya risiko gagal atau macetnya pembayaran atas pinjaman yang telah dipinjamkan kepada masing-masing perusahaan. Dengan adanya penelitian ini, para pemangku kepentingan dapat melihat track recordserta sebagai bahan pertimbangan untuk memilih keputusan serta dapat berhati-hati pada perusahaan yang tergolong sebagai manipulator dan grey company.

\section{DAFTAR PUSTAKA}

Abbas. 2017. Earning Fraud and Financial Stability. Asia Pasific Fraud Journal 2 (1): 117-134 Anugerah, R. 2014. Peranan Good Corporate Governance Dalam Pencegahan Fraud. Jurnal Akuntansi 3 (1). 
Arikunto. 2010. Prosedur Penelitian: Suatu Pendekatan Praktik (Edisi Revisi). Jakarta: Rineka Cipta

Arikunto. 2014.Prosedur Penelitian Suatu Pendekatan Praktik. Jakarta: Rineka Cipta.

Aprillia, Cicilia, dan Rafaela. 2015. The Effectiveness of Fraud Triangle on Detecting Fraudulent Financial Statement: Using Beneish Model and the Case of Special Companies. Jurnal Riset Akuntansi dan Keuangan 3(3):786-800.

Beneish. 1999. The Detection Of Earnings Manipulation. Financial Analyst's Journal (September/October): 24-36

Beneish. 2012. http://papers.ssrn.com/sol3/papers.cfm?abstract_id=1998387 diakses pada tanggal 28 September 2017

Beneish, M. D., Lee, M. C. C. dan Nichols, D.C. 2013. Earnings Manipulation and Expected Returns. Financial Analyst Journal, 69 (2): 57-82.

Cressey, D. R. 1953. Other People's Money. Montclair, NJ: Patterson Smith.

Darmawan. 2016. Analisis Beneish Ratio Index Untuk Mendeteksi Kecurangan Laporan Keuangan. Jurnal Profita Edisi 2(6).

Iqbal. 2010. Pengaruh Tindakan Pencegahan, Pendeteksian dan Audit Investigatif Terhadap Upaya Meminimalisasi Kecurangan Dalam Laporan Keuangan. Skripsi. UIN Syarif Hidayatullah. Jakarta

Kartika dan Irianto. 2010. Penerapan Model Beneish (1999) dan Model Altman (2000) dan Pendeteksian Kecurangan Laporan Keuangan. Jurnal Akuntansi Multiparadigma, 1(2).

Karyono. 2013. Forensic Fraud, Edisi 1. Yogyakarta: ANDI

Mavengere, K. 2015. Memprediksi Perusahaan Kepailitan dan Laba Manipulasi Menggunakan Altman Z-Score dan Beneish M-Score: Kasus Perusahaan Manufaktur di Zimbabwe. International Journal of Sciences Manajemen dan Penelitian Bisnis 4 (10): 8-14.

Munawir. 2010. Analisis Laporan Keuangan. Edisi 4. Yogyakarta: Liberty

Paolone dan Magazzino. 2014. Laba Manipulasi Antara Sektor Utama Industri: Bukti dari Italia. Economia Aziendale Online, 5 (4): 253- 261.

Raharjaputra. 2011. Manajemen Keuangan dan Akuntansi. Jakarta: Salemba Empat

Roxas. 2011. Laporan keuangan Fraud Detection Menggunakan Rasio dan Analisis Digital. Journal of Leadership, Akuntabilitas dan Etika 8 (4): 56-66.

Sekaran, U. dan Bougie, R. 2017. Research Methods for Business. United Kingdom: Jhon Wiley \& Sons Ltd.

Sudarmo., Sawardi, T., dan Yulianto, A. 2008. Fraud Auditing. Jakarta: Pusat Pendidikan dan Pelatihan Pengawasan BPKP.

The Statement of Financial Accounting Concept (SFAC) No.1. 1978. Financial Accounting Standards Board (FSAB).

Tuanakotta, T. M. 2013. Akuntansi Forensik dan Audit Investigatif. Jakarta: LPFE www.finance.detik.com, 2017 diakses pada 19 September 2017.

www.kpk.go.id diakses pada 13 September 2017.

Zulkarnain, R. M. 2013. Analisis Faktor yang Mempengaruhi Terjadinya Fraud Pada Dinas Kota Surakarta. Accounting Analysis Journal. 